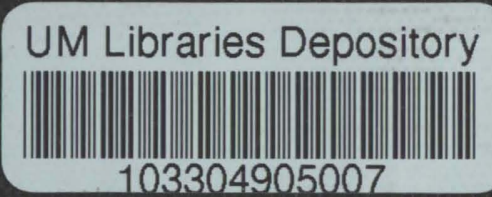




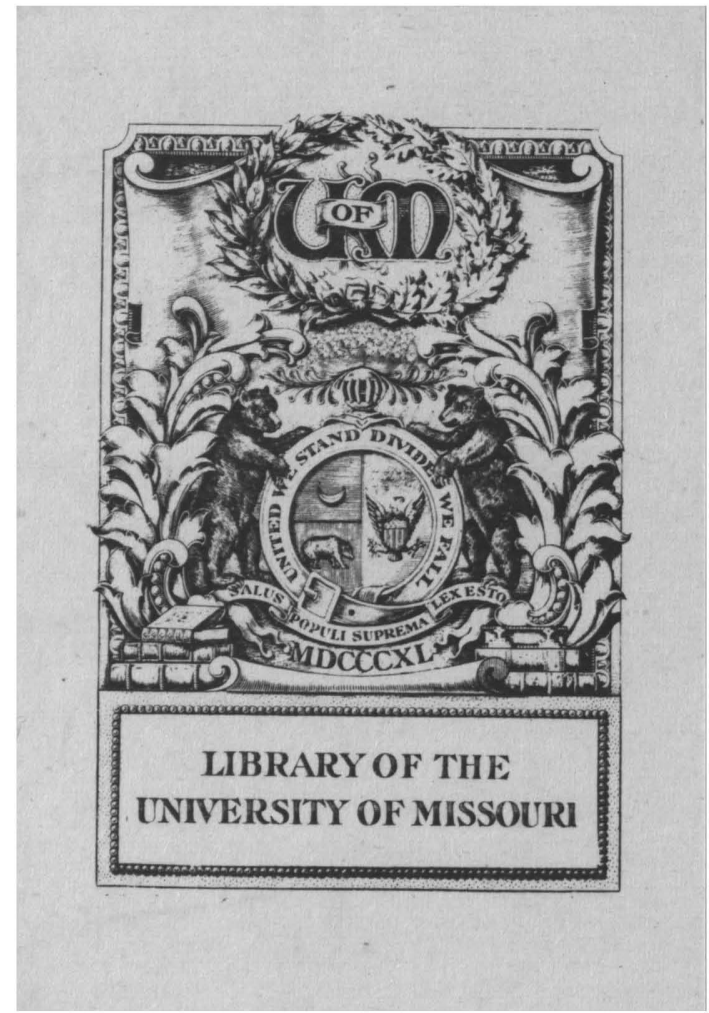

This Thesis Has Been

MICROFILMED

Negative No. T-

207

Form 26 






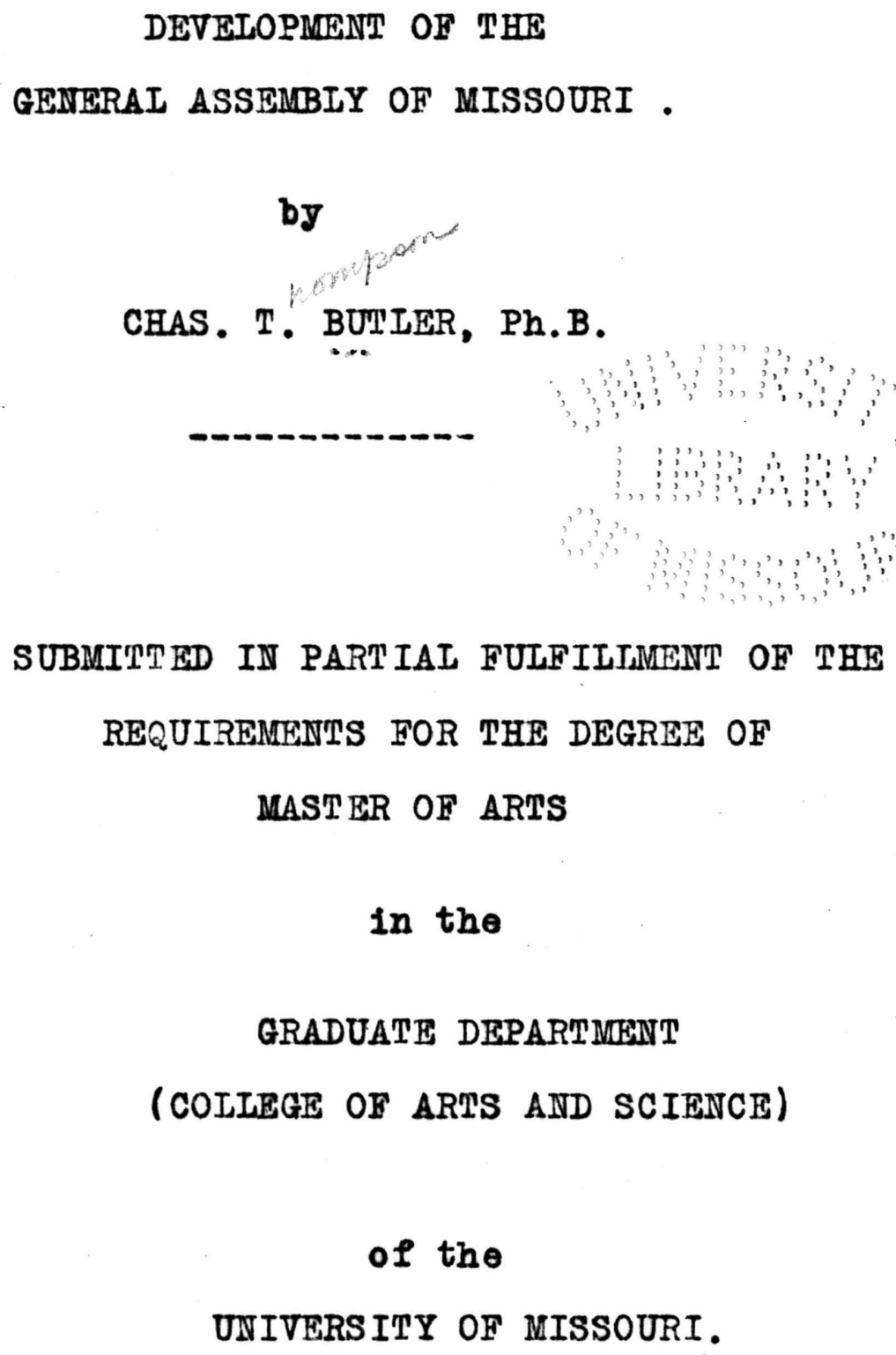

SUBMITTED IN PARTIAL FULFIIIMENT OF THE REQUIREMENTS FOR THE DEGREE OF MASTER OF ARTS in the GRADUATE DEPARTMEANT (COIIEGE OF ARTS AND SCIENCE)

$$
\text { of the }
$$

UNIVERSITY OF MISSOURI. 1908. 

$378.7 \mathrm{M7I}$

$X 897$ 

DEVEIOPNENT OF THE GENERAL ASSEMBIY

OF MISSOURI .

PART I - ORGANIZATION .

CHAPTER I . The Construction of the Iegislative Department.

1- The General Principle of the Legislative Organization. (I).

2- The Suffrage from which the Iogislature Proceeds. (2).

3- The Principle of Representation in the Legislature.

A. In the House of Representatives . (8).

$B$. In the senate (19).

4- Tenure and Term of Members - (27).

5- Qualifications of Members. (29).

6- The Rights and Priveleges of Members . (36).

7- The Assembly and Adjournment of the General Assembly . (41).

8- The Principle of the Quorum in the General Assembly . ( 45$)$.

9- The Internal Organization of the General Assembly . (46).

10- The hode of Legislation in the General Assembly . (49).

(References are to pages.) 



\section{DEVELOPMENT OF THE GENERAL ASSEMBLY}

OF MISSOURI.

PART II.

POWERS .

CHAPTER 1. Introduction . (61).

CHAPTER 2. Powers of the General Assembly under the Constitution of 1820 and Amendments. (63).

CHAPTER 3. Powers of the General Assembly under the Proposed Constitution of 1845 and subsequent Amendments to the Constitution of 1820. (68).

CHAPTER 4. Powers of the General Assembly under the Constitution of 1865 and Amendments. (76).

CHAPTER 5. Powers of the General Assembly under the Constitution of 1875 and Amendments. (86).

Appendix "A", Table showing the apportionment of membership in the Iower House of the General Assembly from 1822 to 1841, inclusive.(118).

Appendix "B", Tables showing the arrangement of counties in senatorial districts, the increase in districts, and the apportionment of senators among districts, from the time of the ddoption of the first Constitution to the present date, inclusive. (119). 

OF MISSOURI .

PART I . ORGANIZATION .

Chapter 1 .

The Construction of the Legislative Department .

1- The General Principle of the Legislative Organization. The Constitution of 1820 established the bicameral system, vesting all power in a "General Assembly", which was to consist of a Senate and a House of Representatives. This general principle of the legislative organization has not been changed by any subsequent constitution.

The name "General Assembly" was given to the legislative body of the Territory of Missouri by the Act of Congress of June 4, 1812, and hes been retained by all the constitutions of the state.

The powers of the two houses in respect to legislation are equal. Bills may originate in either house, and each house may reject those originated in the other. This equality was established by the first Constitution, and has remained - Cons. 1820, Art. III, Sec. 21 - Cons. 1865, Art. IV, Sec. 18 . Cons. 1875, Art. IV, Sec. 27 .) 

2- The Suffrage from which the Legislature Proceeds.

In every community where the sytem of representative government exists, certain qualifications must be possessed by the elector who wishes to exercise the right to vote for representatives. These qualifications will differ in different states, since they are, generally speaking, a reflection of existing social conditions .

At the time Missouri entered the Union, African slavery flourished within her borders. Slaves, of course, were unable to vote, and the same disqualification extended to free negroes.

No person could be a qualified voter, under the first Constitution, who was not a free white male citizen of the United States, 21 years of age or over, and who had not resided within the state one year previous to an election. The last three months of this residence must have been within the county or distriet where the applieant offered to vote - Finally, no seaman, soldier or marine in the regular army of the United States could vote in the State.

From these provisions it is seen that the ballot could be cast by members of the male sex only, and that persons of color, whether free or in slavery, were excluded from voting . (Cons. 1820, Art. III, Sec. 10.)

These provisions of the first constitution of Missouri in regard to the qualifications for suffrage are very simple, and are common to the state constitutions of the 

period. Vastly different are the qualifications imposed for the exercise of this right by the next constitution which became the organic law of the state, that of 1865 . At the period of its adoption, the country had just passed through the throes of an internecine war. Missouri, on account of her geographical location, and the diverse partisanship of her citizens, had been sorely harried by the long and tiresome struggle. Slavery, which had existed within the state sinee the Missouri Compromise and the entrance of the State into the Union, was now a matter of history.

Immediately following the War of Secession, the Republican party, which had stood for the preservation of the Union, and consequently felt little friendahip toward the late Confederate States and their sympathizers, came into control of the state. In the Constitutional Convention of 1865, which was called to reorganize the government of the State, this party dominated. It is not surprising, therefore, to find in the constitution adopted by that body, qualifications imposed which were designed to take the ballot from the hands of all adherents and sympathizers of the confederate States of America.

Such qualifications are found in abundance, so cleverIy and comprehensively arawn, that they effectualy wrested the ballot from the hands of thousands of citizens of the State. It is an historical fact that a certain Brigadier $-3-$ 

General, who had served in the Union army during the war between the states, was denied the right to vote in the State, because he could not bring himself to subscribe to the qualifications imposed by this Constitution. So noted are these constitutinnal provisions in the later history of the state as to excuse their insertion here somewhat at length.

At any election held by the people, and even at any election held in pursuance of any by-law or ordinance of any municipal corporation in the state, no person could be deemed a qualified elector who had ever been in armed hostility to the United States, or her lawful authorities, or to the government of the State, or who had ever given aid, comfort, sustenance or support to persons engaged in such hostility, or who had ever, in any manner, adhered to the enemies, foreign or domestic, of the United States. No person could qualify who had ever, by act or word, manifested his adherence to the cause of such enemies, or his desire for their triumph over the arms of the United States, or his sympathy with those engaged in carrying on rebelition, or exciting rebellion, against the United States.

Further, no person could qualify as an elector, who had ever, except under compulsion, submitted to the authority, or been in the service of the so-called " Confederate States of America ", with the purpose of adhering to the armies of such states.

If any person had enrolled himself, or caused himself to be enrolled, before any officer, as disloyal, or as 

being a southern sympathizer, or in any other terms indicated his disaffection to the government of the United States, in its contest with rebellion, or his sympathy with such rebellion, such person was forever disabled from voting within the State of Missouri, in either state or local elections.

Furthermore, any person who labored under any of the foregoing disabilities could never hold any office of honor, trust, or profit under the state; nor could he be a councillor, airector or trustee in any corporation, public or private, existing at the time of the adoption of the Constitution, or thereafter to be established.

Further, such person could not teach in any educational institution, or common or other school, nor could he hold real estate in trust for any religious association.

(Cons. 1865, Art. II, Sec..1.)

It is needless to comment on the effect of these provisions. Their result was to disfranchise all sympathizers with the seceding states, and to prevent their engaging in certain occupations.

The enforcement of these provisions was accomplished by clauses providing for the registration of all legal voters. When the applicant registered, he must take an oath to the effect that he labored under none of the disqualifications set out above. (Cons. 1865, Art. II, Secs. 4 and 5.)

The above were the negative qualifications for suffrage demanded by the Constitution of 1865. The positive requisites which must be possessed by the voter were sub- 

stantially the same as those imposed by the Constitution of 1820 : Free white male citizenship of the United States, with a proviso that any person of foreign birth, who had declared his intention of becoming a citizen of the Onited State according to law, who was over 21 years of age, might vote, unless he was disqualified by some other section of the Constitution. The evident intention of this clause was to increase desirable foreign immigration into the state, by offering, as an inducement to such immigration, the right to vote at all elections held under the authority of the State - All voters must be residents of the state, for at least one year, and must have resided for the last 60 days of such period in the county or district where they offered to rote.

It is to be noted that the voter, under this constitution, must have been a free white male. The right of suffrage was not jet conferred upon the freed slave. After the passage of the Fifteenth Amendment to the Federal Constitution, which ocourred in 1870, he could not lawfully be denied this privelege by any State. This provision of the Constitution of Missouri, in so far as it denied the suffrage to the freedman, thereby became null and void.

We have considered the most interesting of the various qualifications which have been imposed upon legal voters in Missouri. At present the right is conferred upon alidult male Izens of the United States, and upon every male person of fareign birth who may have declared his intention of becom- 

ing a United States citizen according to law, not less thar one year nor more than five years before he offers to vote, and who is over the age of 21 years; provided that such person shall have resided in the state one year immediately preceding the election at which he offers to vote, and 60 days immediately preceding the election in the county, city, or town where he offers to vote.

(Cons. 1875, Art. VIII, Sec. 2.)

A new disqualification is introduced by the present constitution, in that no person, while kept in any poor house, or other asylum, at public expense, nor while confined in any public prison, shall be entitled to vote at any election held under the authority of the state.

(Cons. 1875, Art. VIII, Sec. 4.)

Furthermore, the Gineral issembly may, in the exercise of its discretion, pass laws excluding from the right of voting all persons convicted of felony or other infamous crime, or misdereanor connected with the exercise of the right of suffrage. (Cons. 1875, hrt. VIII, Sec. 10).

In 1895, the General Assembly availed itself of the privelege conferred by this section.

$$
\text { (Seo R.S.1899, Sec. 7346). }
$$

Finaliy, following the example set by the constitution of 1820 , no officer, soldier, or marine in the regular army of the United states is entitled to vote in any election in the state. (Cons. 1875, srt. VIII, Sec. 11). 

3 . The Principle of Representation in the Legislature.

A. In the House of Representatives.

In the history of Missour1, representation in the General Assembly has been apportioned among certain designated olasses of population. This plan adopted when the Territory of Missourl was formod, and was followed until the Constitution of 1865 was adopted . The olagses of popvlation acoording to which representation has been apportioned have ohanged several times during the history of the State .

Onder the first oonstitution, it was provided that representatives should be apportioned among the different counties according to the number of free white male inhabitants. The ratio of representation was fixed by the General Assembly, but the total number of representatives could not exceed 100, and oach county was ontitled to one representative . (Cons. 1820, Art. III, Sec. 2.)

Th1s apportionment, according to the number of free white meles, follows the plan used for apportionment in the House of Representatives during the territorial period of what is now the State. The Act of Congress of June 4, 1812, provided that the House should be composed of members elected every second year by the people of the Territory, in the ratio of one representative to every 500 free white male inhabitants, until the number of rep resentatives should reach 25 , after which the number and

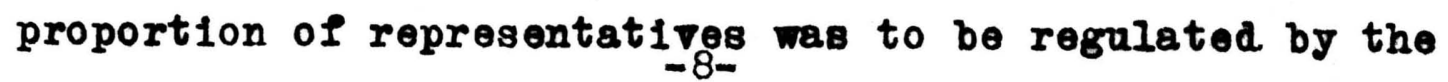



General Assembly . (U.S.Statutes at Large, Vol.II, p. 745.)

The next change in the class of population according to which representation was to be apportioned was suggested by a draft constitution, submitted to the people of the State in 1845. This instrument proposed, as a substitute for the free white male inhabitants of the Constitution of 1820, simply permanent free white inhabitants. Had this provision been adopted, women would have been counted in the olass of population used for apportioning representatives among the different counties.

As the proposed constitution was not ratified, this provision did not become effective. In 1848, an amendment to the constitution was adopted, fixing the apportionment for representation. This amendment adopted the suggestion proposed in 1845, and apportioned representation, in the House of Representatives, according to permanent free white inhabitants.

By the Constitution of 1865, Art. IV, See. 3, it was declared that representation should be apportioned among the " permanent inhabitants " of the state. This is by far the most significant change ever made by the state in the definition of the class of population at the basis of representation. The provision is chiefly the result of the Civil War and the abolition of slavery . All distinctions of sex, color, and servitude are eliminated in counting population for purposes of representation.

The same principle is followed in the present constitution, representation being apportioned among the whole 

number of inhabitants of the state, the phrase " permanent inhabitants", which was used by the Constitution of 1865, and which seems to have been practically meaningless, not being retained. (Cons. 1875, Art. IV, Sec. 7.)

During the time that Missouri has been a state, various plans have been tried, at different periods of the State's history, for apportioning the representation in the House of Representatives among the class of population serving as the basis of apportionment. As mentioned above, an act of Congress had fixed the ratio of representation in the House during the territorial period at one representative for every 500 free white male inhabitants. When the number of representatives reached 25, the General Assembly was to regulate the number and proportion of representatives.

Under the first constitution of the state, the ratio of representation was fixed by the General Assembly, but the number of representatives could not exceed 100, and each county was entitled to one representative. (Cons. 1820, Art. III, Sec. 2.) For the purpose of determining the number of free white males in each county, the General Assembly was required, at its first session in 1820, and at its sessions in 1822, 1824, and every fourth year thereafter, to provide for a state census. The General Assembly, in 1822, and at each apportioning session thereafter, fixed the ratio of apportionment, and assigned each county in the state a specific number of representatives, proceeding on the basis of the state census which was taken under its 

authority - (These apportionments will be found in Appendix "A", at the end of this dissertation).

The Constitution itself had fixed the apportionment of representation for the various counties for the first session of the General Assembly.

We find no evidence of dissatisfaction with this plan until 1845 . In that year a Constitutional Convention was called in this state, which drafted a new constitution, that failed, however, to be ratified by the people when submitted to them at election. Had this instrument been adopted it would have changed very materially the existing method of apportioning members of the House of Representatives among the various counties. The rule fixed by this instrument for determining the apportionment was as follows: The whole number of permanent free white inhabitants of the State was to be divided by the number 100, in order to determine the ratio. Each county whioh had three fifths of the ascertained ratio was entitled to one representative; each county which had said ratio and a fraction over equal to two thirds,was entitled to two representatives; each county which had twice said ratio and a fraction over equal to two thirds, was entitled to three representatives; each county which had four times said ratio was entitled to four representatives, and so on in proportion above that number, giving each county one additional representative for each additional ratio it possessed . (Cons. 1845, Art. III, Sec.2.)

In order to appreciate the effect of this rule in allotting representatives to the different counties, let us presume a hypothetical case. If the whole number of per$-11-$ 

manent free white inhabitants of the state in. 1845 was 400,000 , by dividing this number by 100 , the ratio is found to be 4000. A county having three fifths of this ratio, or 2400 permanent free white inhabitants, was entitled to one representative, while a county having four times the ratio, or 16,000 , was only entitled to four representatives.

Clearly, under this plan, the small counties of the State would have had undue representation at the expense of the larger counties. We are led to seek some reason for this proposed change. It is found in the apportionments made by the General Assembly for the counties at the various apportioning sessions between 1820 and the time of the draft constitution. (These apportionments will be found in Appendix "A" at the end of this dissertation.) From these apportionments we draw an inference that will explain why the rule proposed in 1845 would have given the smaller counties such a startling advantage over the larger counties in the matter of representation. These figures show that the larger counties had been allotted a representation which gave them great power in the matter of legislation, and it is apparent that the rule proposed in 1845 was a reaction against this condition.

As is well known, this constitution was never adopted by the people of the state. While the provisions mentioned above fell with the whole of that instrument, it is evident that a demand existed for a change in the rule of apportionment, as is shown by the adoption in 1848 of a constitu- 

tional amendment which had been proposed by the General Assembly in 1847, which radically changed the rule.

(Laws of Mo., 1847, page 7. Ratified, Laws of 1848, page 6). This amendment followed the general principle at the basis of the draft constitution of 1845 in regard to apportionment, but was more extreme in favor of the small counties. This will appear from a statement of the rule enunciated by the amendment.

The ratio of apportionment was to be ascertained at each apportioning session of the General Assembly, which was the session immediately succeeding the taking of the census, which it will be remembered, was to be taken every fourth year. The method of obtaining the ratio was as follows: The whole number of permanent free white inhabitants of the state was to be divided by the number 140 . Upon the basis of this ascertained ratio the representation of each county was to be determined. Each county having said ratio or less was given one representative. Each county having said ratio and a fraction over equal to three fourths was entitled to two representatives; each county having three times said ratio was entitled to three representatives; each county having four times the ratio and a fraction over equal to one half, four representatives; each county having ix times the ratio, five representatives; each county having eight times the ratio, six representatives: each county having ten times the ratio, seven representatives; each county having thirteen times 

the ratio, eight representatives; each county having fifteen times the ratio, nine representatives; each county having eighteen times the ratio, ten representatives; each county having twenty- two times the ratio, eleven representatives; each county having twenty-four times the ratio, twelve representatives; and any county having more than twenty four times the ratio, representation in proportion.

As was said above, this system gave undue preference to the small counties: To illustrate, a county having only three times the ratio would be, under this rule, entitled to three representatives; while a county having twenty four times the ratio only received twelve representatives. This gave the small county representation in the proportion of two to one.

Notwithstanding this fact, the rule as established remained in force for serenteen years, until the Constitution of 1865 was adopted.

Onder this constitution, the ratio for purposes of apportionment was determined by dividing the whole number of permanent inhabitants of the state by the number 200. Each county having one ratio was entitled to one representative, and no county could have less than one representative, whether possessing the required ratio or not. Each county with three times the ratio received two representatives; each county with six times the ratio, three representatives, and so on in proportion, giving each county one additional representative for every three additional ratios it could show - (Cons. 1865, Art. IV, Sec. 3.) 

This rule equalized to some extent the disproportion which existed between the representation of the large and small counties, except as regards the smallest counties, that is, those having less than a ratio of representation. Under this rule, such a county enfoyed greater proportionate representation than under any of the previous rules.

Apportionment in the House of Representatives was determined according to this rule for ten years, until the Constitution of 1875 was adopted, by which the apportionment is determined at present.

The rule for determining the ratio is the same as under the previous constitution. The whole number of permanent inhabitants of the state is divided by the number 200. But a change was made in the amount of representation each county was entitled to for the ratios of population it possessed. No county can have less than one representative; each county having two and one half times the ratio is entitled to two representatives. Each county having four times the ratio receives three representatives, and each county having six times the ratio, four representatives - Above that number, one additional representative is allowed for every additional two and one half ratios.

This rule does not discriminate among as many classes of counties as did the rule of 1865 . On the other hand, it increases the undue advantage, possessed by the smallest counties, in the matter of representation. 

We have considered the various rules of apportionment which have been in force in the state for determining representation in the House of Representatives . A consideration of these rules embraces by far the most important features of the development of the apportionment; but there are certain minor features whose significance justify their insertion here.

Provision was made in the proposed constitution of 1845 for separate representation for cities of a certain population, when such cities had a population equal to a ratio of apportionment, and when the county in which such a eity was located had a population equal to a ratio of apportionment, exclusive of such city. If the tow or city should show itself entitled to more than one representative, it was to be divided into districts by the general county authority, and each of these districts should elect one representative. The significance of this provision lies in the fact that it distinguishes between urban and rural population, in the matter of representation, and is the first constitutional proposal, in the State, for the single ticket plan of election . (Cons. 1845, Art. III, Sec. 2.) The former has never been carried into effect, but the latter plan was incorporated in the constitution of 1865, in the provision that counties which were entitled to more than one representative were to be divided into convenient and compact distriots, and that the qualified voters of such district were to elect one representative, who was to be a resident of such district. (Cons. 1865, Art. IV, Sec. 7.) 

Practically the same provisions are found in section 3 of Article IV of the present constitution.

The state census, which was authorized to be taken under the authority of the General Assembly every fourth year after 1824, was retained until 1865, after which time it was to be taken only every tenth year, and used alternately with the census of the United States, for the purpose of determining the population of the state. In 1875, this plan also was discontinued, and the state census is to be used today only in the event that the regular census of the United States should fail to be taken. (Cons. 1865, Art. IV, Sec. 7. Cons. 1875, Art. IV, Sec. 7.) 

B. The Principle of Representation in the senate.

In the Constitutional Convention of 1820 a proposal was made to give every county in the state, large and small, an equal representation in the senate, a plan analogous to the commonwealth equality in the Senate of the United states .

During the territorial period, the senate passed through two stages. It was at first, under the Act of Congress of June 4, 1812, a body called the Iegislative Council, consisting of nine members, appointed by the President of the United States, from among eighteen nominees, selected by the territorial House of Representatives. The Councillors held office for five years, unless sooner removed by the President.

By the Act of Congress of April 29, 1816, the Legislative Council was made an elective body, its members being chosen by the electors of the Territory, at the same time they chose representatives, to hold office for the term of two years only. One member of the Council was to be elected from each county in the Territory.

The plan which was proposed in the Constitutional Convention of 1820 , of giving each county in the state an equal representation in the Senate, was therefore only a continuation of the plan which had been used during the territorial period. Altho this proposal met with some degree of favor, it was vigorously opposed on some sides, and was ultimately abandoned. (see Missouri Intelligencer, July 12, 1820.)

\section{-19-}



The first constitution fixed the membership of the Senate at not less than 14 nor more than 33. (Cons. 1820, Art. III, Sec. 6.) This provision followed the plan, common to all the states in the Union, of having the upper house in the legislative body smaller than the lower house, a condition which had obtained during the territorial period.

With a single exception, the same classes of population have been counted for purposes of apportionment in the senate as were used in determining representation in the House of Representatives. Wherever these classes have been changed by the Constitution, the change applied equally to both houses. Since these changes were discussed somewhat at length in considering apportionment in the House, no extended treatment need be given to them here.

The exception referred to is the Amendment of 1848 , which changed the class of population by eliminating the restriction to males. This amendment applied only to the House of Representatives.

In apportioning representation in the House, the county was the area of representation employed. For the senate, however, on account of its smaller size, it was necessary, in most cases, to adopt some larger area than the county. The Constitution of 1820 provided that the state was to be districted for the election of senators. Provisions regarding these districts intended to prevent gerrymandering will be noticed later.

Senators were to be apportioned among these districts according to the number of free white male inhabitants in $-20$ 

each. (Cons. 1820, Art. III, Sec. 6.)

For the first election of senators, the Constitution fixed the minimum number of 14, who were to be apportioned among nine districts. The General Assembly had the power to fix the future apportionments, and to determine the number of senators within the limits fixed by the Constitution.

The Act of the General Assembly of Jan. 12, 1822, which provided the apportionment of representatives among the counties, also fixed the representation in the senate. (Territorial Laws of Missouri, 1804-1824, page 906 .) The ratio of representation was one senator for every 1850 free white males, as near as circumstances would allow, without dividing counties. The total number of aistricts was increased to 14, and the number of senators to 17 , three of the districts electing 2 senators each.

During the remainder of the period that the Constitution of 1820 was in force, the General Assembly, at its apportioning sessions, revised the apportionment of senators, as it did that of representatives, upon the basis of the state census. (For these apportionments see Appendix " $B$ " at the end of this dissertation). From these apportionments it will be noted that the number of districts and the number of senators increased to 29 and 33 resepctively.

Had the draft constitution of 1845 become the organic law of the state, the apportionment of senators would, of course, have been made according to the number of permanent 

free white inhabitants of the state.

The Constitution of 1865 fixed the size of the Senate at 34 members, leaving to the General Assembly the duty of erecting senatorial districts. (Cons. 1865, Art. IV, Sec. 4) As each district could elect only one senator, the number of districts was the same as the number of sonators.

A county which was entitled to more than one senator was to be divided into as many districts, each of which was to elect one senator.

Senators were to be apportioned according to the number of permanent inhabitants of the state, and the apportionment was to be revised upon the basis of the next decennial census of the United States and of the state, as indicated previously in the case of representatives.

$$
\text { (Cons. 1865, Art. IV, Sec. 7.) }
$$

When we examine the present constitution in this respect, we find that the provisions of the constitution of 1865 are practically reenacted, with the omission of the requirement for a State census. The number of senators remains 34; the State is to be divided into districts for their election; these aistricts are to be as nearly equal in population as possible, and their population is to be ascertained by the next preceding decennial census of the United states. (Cons. 1875, Art. IV, Sec. 5).

Upon the basis of this census the apportionment is to be revised every ten years, or upon the basis of a state census if the national census is delayed or not taken. (See Appentix "B".

$$
-22-
$$



(Cons. 1875, Art. IV, Sec. 10.) The Article proceeds to divide the state into 34 senatorial districts, each to elect one senator, until the apportionment should be made according to the rule established . (Section 11.)

A new provision was introduced for the contingency that the General Assembly should fail to district the state for senators . It was made the duty of the Governor, Secretary of state, and Attorney General to exercise this function, within thirty days after the adjournment of the General Assembly at which this duty should have been performed . Certain formalities are to be observed in making the division, and upon proclamation by the Governor, this districting is made as binding as if made by the General Assembly - (Cons. 1875, Art. IV, Sec.7 .)

This section, which empowered several executive officers to district the state in the event of a failure by the General Assembly to do so, is a most important safeguard. If the General Assembly should fail to make the division into senatorial districts, and there was no other method provided for making the division, senators would be apportioned according to the districts formed by the last preceding General Assembly. The effect of this would be, in some cases, unjust. Thus a county, which under the preceding apportionment, formed a senatorial district with two other counties, might, on account of an increase of population, form a senatorial district itself, and be entitled to elect one senator; but if the redistricting had not been made, such county, notwithstanding its increase 

in population, would have to follow the old apportionment, and with the two other counties, elect 'one sonator.

This power vested in the Governor and the two other State officers has been twice exercised. The Thirty. Sixth General Assembly adjourned without redistricting the state for senators, and on the 23rd. day of April, 1891, the Governor, Secretary of State and Attorney General met and performed this duty, under the authority vested in them by the constitutional provision discussed above. The FortyFirst General Assembly also failed to perform this duty, and the officer empowered to do so redistricted the state on Apri1 6th., 1901. (See Appendix "B".)

The preceding discussion indicates the general phases of development of the apportionment of senators in Missouri under the various constitutional provisions governing the subject. It should be emphasized that while the principle of representation in the House of Representatives gives undue advantage to the smaller counties, in the senate the principle of representation according to population obtains, subjeot only to the exception that a county shall not be divided in forming a senatorial district, unless it is entitled to more than one senator.

Certain minor phases of the development of representation in the Senate also command our attention.

Under the Constitution of 1820 it was provided that senatorial districts should be cenvenient . Moreover, where a distriot was composed of two or more counties, these counties could not be separcted by any county belonging to $=84=$ 

another district; nor could any county be divided in forming a senatorial district . (Cons. 1820, Art. III, Sec.6) These rules, which have been reenacted by the two succeeding constitutions, were designed to prevent gerrymandering for political purposes.

The proposed constitution of 1845 would have annulled the provisions of the first constitution in so far as it provided that no county could be divided in forming a senatorial district, as this later instrument expressly provided for the division of such counties as were entitled to elect more than one senator. They were to be divided into as many districts as they were entitled to senators, each district to contain as nearly as possible an equal number of free white inhabitants. This division was to be made after each apportionment of the state, and could not be changed until after the next succeeding apportionment . (Cons. 1845, Art. III, Sec. 6 .)

These requiremente proposed by the draft constitution of 1845 were practically reenacted by the Constitution of 1865 . If senatorial districts were composed of two or more counties, these counties must be contiguous . A new provision was inserted to the effect that when a county was divided for the election of senators, the districts into which it was divided must be compact and convenient. This clause was designed to prevent political gerrymandering within the county. (Cons. 1865, Art. IV, Sec. 5.)

In regard to senatorial districts, the Constitution of 1875 introduces no new provisions, (Art, IV, Sec. 5). 

The last phase of the principle of representation in the Senate which we shall notice is the division of its members into two classes . By the Constitution of 1820 , when the senate met at its first session, it was to divide its members by lot into two classes, as nearly as possible equal in number. The seats of the first class were vacated at the end of two years, but the seats of the second class did not become vacant until the end of four years. Thus one half of the senators were chosen every two jears, to hold for a period of four years . (Cons. 1820, Art. III, 7.) This plan of gradually changing the membership of the upper house has remained in the succeeding constitutions of the state, altho the plan of division was changed by the Constitution of 1865 , members elected from districts bearing odd numbers retiring at the end of the second year after the first election held under that constitution, while members from districts bearing even numbers held over until the end of the fourth year. (Cons. 1865, Art. IV, Sec. 10). This plan is followed in the present constitution by Sec. 10 of Artiole IV.

There is seen in these provisions a noticeable difference in the renewal of membership in the House of Representatives and in the senate. In the former the change is total at the end of every biennial period; the whole number of representatives being elected then; in the latter the change is only partial, only one half of the senators being elected every two years. The plan is modeled upon the Congress of the United States. 

4- Tenure and Term of Members in the General Assembly of Missouri.

The tenure by which membership in the General Assembly is held is elective. This has been so since the adoption of the first Constitution, and applies to both branches of the legislative body.

During the territorial period tenure in the lower house of the territorial legislature was elective, but members were appointed to the territorial senate, or Legislative Council, as it was called, by the President of the United states, to hold for a period of five years, unless sooner removed by him.

However, the provisions of the Constitution of 1820 applied the principle of elective tenure to both houses. The House of Representatives was to consist of members chosen every second year by the qualified electors of the several counties. Their term of office was two jears. (Cons. 1820, Art. III, Sec. 2.)

Senators were to be chosen by the qualified electors to hold for a term of four years . (Cons. 1820, Art. III,5.)

We noted in the discussion of apportionment in the Senate that its members were divided into two classes, each class comprising one half the membership of the body. Following this plan of division, one half the membership of the Senate was elected every second year.

These general principles of tenure and term of mem$-27-$ 

bers of the General Assembly have been retained by all

the subsequent constitutions of the state.

(Cons. 1845, Art. III, Secs. 2 and 4. Cons. Amend. 1847,

Iaws 1848, page 6. Cons. 1865, Art. IV, Secs. 1 and 4.

Cons. 1875, Art. IV, Secs. 2 and 4.) 

5- Qualifications of Members of the General Assembly of Missouri .

The principal qualifications which have been imposed upon members of the General Assembly are three: Age, Citizenship, and Residence. We shall consider the two houses separately in this respect.

A- The House of Representatives .

Under the provisions of the first Constitution, no person could be eligible to membership in the House of Representatives unless he was 25 years of age, a free white male citizen of the United states, a resident of the State two years, and of the county which he represented for one year next preceding his election. If the county had not been established for that length of time, he must have been a resident for one year of the county or counties from which his county was formed.

In the Constitutional Convention of 1820 lower qualifications had been proposed for membership in the House than were demanded by the Constitution of 1820 when it was adopted. A motion was made in the Convention to make all persons eligible to membership in the House who were citizens of the United States, 21 years of age or over, and who had been residents of the state for a period of six months prior to the adoption of the Constitution, but this motion was lost . (Convention Record, 1820, page 16.)

In addition to the qualifications mentioned above, 

the Constitution of 1820 required of all members of the House the payment of a state or county tax.

(Cons.1820, Art. III, Sec. 3.)

The proposed constitution of 1845 reenacted these provisions without material change - (Cons, 1845, Art. III,3).

The next change made in the qualifications of members of the House is found in the Constitution of 1865, which reduced the age requirement to 24 years . The word "free" before "white males" was omitted, but this omission produced no practical change.

The present Constitution only slightly changes the provisions of the preceding constitution in this respect. It requires that the state or county tax shall be paid within one year next preceding the election. (Cons. 1875, Art. IV, Sec. 4.) "Male citizens" are eligible, instead of "white male citizens", following the general tendency, since the abolition of negro slavery, to remove restrictions imposed upon persons of African descent.

\section{B- The Senate.}

The positive qualifications which must have been possessed by senators under the Constitution of 1820 were four years residence in the state, lone year in the districts from which they were elected), free white male citizenship of the United States, the attainment of thirty years of age, and the payment of a state or county tax.

It is to be noted that senators must have been considerably older than members of the House of Represent- 

atives. Four yeurs residence in the state is required, as against two for representatives. The reason for these differences lies in the fact that these qualifications tend to insure conservatism in legislation. The theory is that the upper house, composed of members older and of more mature judgment than those of the lower house, will afford a check upon rash and ill-considered legislation.

$$
\text { (Cons. 1820, Art. III, Sec. 5). }
$$

The Constitution of 1865 introduced the next change in the qualifications of senators. Three years residence in the state as a qualified voter was required for eligibility, and the restriction to free white male citizens was eliminated. White male citizens were made eligible.

$$
\text { (Cons. 1865, Art. IV, Sec. 5). }
$$

No change in the requirements as to age and residence was made by the Constitution of 1875, but the qualifications as to citizenship were lowered, the word "white" being omitted, and male citizens of the United states were made eligible to the senate. The reasons for this change were noted in the discussion of qualifications for members of the House of Representatives. (Cons. 1875, Art. IV, Sec. 6).

Under none of the Constitutions of the state has merbership in either house of the General Assembly been accorded to Lomales.

The foregoing are the only positive qualifications which have been demanded of menbers of the General Assembly of Missouri by the several constitutions of the state. 

But dating from the first constitution, various disqualifications have been made a bar to membership in either house of the legislative body. These disqualifications may be conveniently divided into three classes : Conviction of crime, office holding in religious associations, and tenure of public offices.

Bribery was made a disqualification in this respect by the Constitution of 1820 . The provision was sweeping in its effect, forever debarring from any office of honor, trust, or profit, any person who should have been convicted of directly or indirectly giving or offering any bribe to procure his election or appointment to any office. (Cons. 1820, Art. III, Sec. 15.)

This provision was incorporated in the proposed constitution of 1845, but is not found in the two succeeding constitutions.

The disqualifications resulting from the exercise of religious functions were enacted in the first Constitution, and continued by the proposed constitution of 1845, but did not appear in the two later constitutions. Their substance was that no person could be eligible to either branch of the General Assembly while he exercised the functions of a bishop, priest, clergyman, or teacher in any religious denomination, society, or sect.

$$
\text { (Cnns, 1820, Art. III, Sec. 13.) }
$$

Nembership in the General Assembly has always been denied to the incumbent of any office of a public nature within the state, with a few exceptions. Under the Con$-32-$ 

stitution of 1820 this disqualification extended to the judge of any court of law or equity, the secretary of state, attorney-general, state auditor, state or county treasurer, registrar or recorder, clerk of any court of record, sheriff or coroner, member of congress, or any other person holding a lucrative office under the United States, or the State of Missouri, except militia officers, justices of the peace, and postmasters. (Cons. 1820, Art. III, Sec. 11 .) The present constitution extends these disqualifications to officers in any municipality of the State, as well as to those engaged in the administration of general state jurisdiction .(Cons. 1875, Art. IV, Sec.12).

These rules find their reason in the theory of American government, in the states, which demand that the three departments shall be kept separate and distinct .

A further disqualification imposed by the Constitution of 1820 upon membership in the General Assembly was that no senator or representative could be appointed, during the term for which he was elected, to any civil office under the State, which office had been created, or the emoluments of which had been increased during his continuance as a member of the legislature, except to such offices as were filled by elections by the people. The obvious purpose of this provision was to prevent any legislator from having any office created, or the salary of any office increased, with the intention that he himself should be appointed to fill it . (Cons. 1820, Art. III, Sec. 16.) 

No collector of public money, nor any assistant or deputy of such collector, who had not accounted and paid to the state all sums for which he was responsible, could be eligible to either house of the General Assembly under the Constitution of 1820. This provision, which is not retained by the present constitution, al tho found in the Constitution of 1865, prevented the possibility of any legislator, through his influence as a member of the General Assembly, making valid by legislation any deficit which might have occurred in his accounts as a collector of the revenue . (Cons. 1820, Art. III, Sec. 12; Cons. 1865, Art. IV, Sec. 12.)

Remotal from the county or district wherein a representative or senator has been elected will vacate his seat in the General Assembly. The obvious reason for this rule is that such a member no longer represents the people who elected him. (Cons. 1865, Art. IV, Sec.13. Cons. 1875, Art. IV, Sec. 13.)

A disqualification which tends to keep legislation free from railroad influence is found for the first time in the Constitution of 1875, where it is declared that the seat of any member of the General Assembly shall be vacated who accepts free passes, or tickets, or passes or tickets at a discount, from any railroad company within the state. (Cons. 1875, Art. IV, Sec. 24.)

The Constitution of 1875 also imposes upon legislators a further qualification which is that they must take an 

oath, prescribed by Section 16 of Article IV . The substance of the oath is that the Representative or Senator will support the Constitution of the United States, and of the State, faithfully perform the duties of the office, and receive no reward for their performance other than the compensation allowed by law. Refusal to take this oath is held to be a vacation of the office; a violation of the oath is perjury, punishable as such, and disqualifies the perjurer from holding any office of trust or profit under the authority of the State. 

6. The Rights and Priveleges of Nembers of the General Assembly of Missouri .

From the time of the first Constitution, members of the General Assembly have had a constitutional right to be paid a compensation for their services. The Constitution of 1820 did not specify the amount of such compensation, but provided that it was to be paid from the public treasury, and might from time to time be increased or diminished by law - For obvious reasons, no alteration, increasing or tending to increase this compensation could take place during the session at which such alteration was made.

$$
\text { (Cons. 1820, Art. III, Sec. 24.). }
$$

This provision, which is common to many state constitutional provisions on the subject, following the Constitution of the United States, gave to the legislature the power of fixing the compensation of its members. The latter clause of the section prevented legislators from raising their own salaries while in office. These sections were adopted by the proposed Constitution of 1845. (Art.III, Sec.4)

The next change made in the salaries of members of the legislature by constitutional provision was effected by an amendment to the Constitution, proposed in 1847. This amendment gave members of both houses compensation at the rate of three dollars per day for the first sixty days of the session, and after that time an amount not to exceed one dollar per day for the remainder of the session. At a revising 

session members might receive as much as three dollars per day for the first one hundred days, and one dollar per day for the remainder of the session. By a revising session is meant a session of the General Assembly at which the laws of the state are revised by that body, and published in revised form under its authority. One such session is held every ten years.

In its discretion, the General Assembly might allow the presiding officers of each house a greater compensation than that provided for members generally. (Laws of Missour1, 1847, Page 6, Proposed - Laws of Missouri, 1851, page 40,Ratified .)

The purpose of thus fixing the salaries of members of the General Assembly by Constitutional enactment, and decreasing that compensation after a certain number of days of the session had elapsed was to prevent the sessions of the General Assembly from continuing for an undue length of time. The draft constitution of 1845 would have restricted the length of anj session to 60 days. The plan inaugurated by the Constitutional Amendment of 1847 discouraged long sessions, while it still left a discretion to the General Assembly in the matter of length of sessions.

By a subsequent constitutional amendment, proposed by the General Assembly in 1856, and subsequently ratified, the amendment of 1847 was formally abolished, and consequentIf the original provisions of the Constitution of 1820 again beoame of full force and effect, so that the General Assembly again fixed the compensation of 1 ts members. 

(Laws of Missouri, 1856, Page 5, Proposed. Laws of Missouri, 1857, p.5,6, Ratified.)

The Constitution of 1865 did not disturb the provisions of the Constitution of 1820 in this respect.

(Cons, 1865, Art. IV, Sec. 17.)

The provisions of the present Constitution in this respect adopt the same policy as did the Constitutional Amendment of 1847 . They tend to discourage undue prolongation of legislative sessions. The General Assembly fixes the compensation, but it oannot exceed five dollars per day for the first seventy days of the session, and after that not more than one dollar per day for the remainder of the session. Exceptions to the latter clause are made for the first session held under the Constitution, and for revising sessions, when members may receive five dollars per day for 120 days, and one dollar per day for the remainder of the session.

In adition to per diem, members receive traveling expenses, or mileage, for regular and extra sessions. This compensation cannot exceed the amount fixed by the General Assembly for this purpose, at the time the Constitution was adopted. No member can receive traveling expenses or mileage for any extra session that may be called within one day after the expiration of a regular session, since, for such sessions, members are supposed to have remained at the seat of government.

Committees of either house, or joint committees of both houses, appointed to examine the institutions of the 

State, other than those at the seat of government, may receive their actual expenses, necessarily incurred while in the performance of such duty. The manner in which all accounts for such expenses are to be certified and paid is provided by the Constitution.

Each member may receive at each regular session an additional sum of \$30, which shall be in full for all postage, stationery, and other incidental expenses incurred by him in his official capacity. All other allowances and emoluments whatsoever are strictly forbidden to be received by any member of either house of the legislative body.

(Cons. 1875, Art. IV, Sec. 16).

This provision deprived the General Assembly of any power to fix the compensation of its members. That this compensation is thought to be too low at the present time is evident from the fact that a constitutional amendment to be submitted to the people in November, 1908, proposes to increase the compensation of members of both houses to $\$ 750$ per jear.

Merbers of the legislature are priveleged from arrest, in all cases except of treason, felony, and breach of the peace, during the sessions of the General Assembly, and for a period of 15 days immediately preceding and succeeding such sessions. This immunity was inaugurated by the Constitution of 1820, is common to all state Constitutions, and is found in the constitution of the United States. The obvious purpose of this privelege is to prevent interference with legislation. (Cons. 1865, Art. IV, Sec. 16. Cons. 1875, Art.XIV, Sec. 12). $-39-$ 

Freedom of speech is a further constitutional privelege granted to member of the General Assembly of Missouri. They cannot be questioned in any other place for any speech or debate in either house. This clause insures the members of each house from suits for libel or slander founded on any utterance made by them while participating in the legislative procedure of either house, and fixes their responsibility for such utterance to the house to which they belong .

(Cons. 18 0, Art. III, Sec. 23. Cons, 1845, Art. III, Sec. 23. Cons. 1865, Art. IV, Sec. 16. Cons. 1875, Art.XIV, Sec. 12.) 

7. The Assembly and Adjournment of the General Assembly of Missouri.

The Constitution of 1820 fixed the time of meeting for the First General Assembly as the third Monday in September, 1820; further sessions were to be held on the first Monday in November, 1821 and 1822 , respectively . After that biennial meetings were to convene on a day to be fixed by the General Assembly; but if no date was fixed by that body, its meetings were to commence on the first Monday in November. (Cons. 1820, Art. III, Sec. 33.) Under the proposed constitution of 1845, the first Monday in November, 1848, was selected as the date for the first session of the General Assembly held under its authority. The Constitution of 1865 chose the first Wednesday in January as the date for the first meeting of the General Assembly held under the authority of that instrument. Regular meetings thereafter were to convene on that day in alternate years, but the legislature might in its discretion select a different date. (Cons. 1865, Art. IV, Sec. 35.)

The present Constitution requires that the General Assembly shall meet in regular session every two years, on the first Wednesday in January, and gives that body no discretion to change the day. (Cons. 1875, Art. IV, Sec.20.)

It is to be noted from the above provisions that regular sessions of the General Assembly can be held only once in two years; but by all three constitutions of the state the Governor is expressly empowered to call the legislature $-41-$ 

in extra session by proclamation, stating in his proclamation the purposes for which the legislators have been convened in extra session. This power was first given by Section 7 of Article IV of the Constitution of 1820, but this provision did not expressly prohibit the General Assembly, when once convened in extra session, from considering matters not set forth in the proclamation of the Governor. In order to prevent this, the constitution of 1865, by an express provision, forbade the consideration, at extra sessions, of any matters not enumerated in the proclamation of the Governor. (Cpns. 1865, Art. $\nabla$, Sec. 7.)

This provision is retained by the constitution of 1875, with the addition of a clause allowing the consideration, at extra sessions, of matters that may be recommended to the General Assembly by the Governor, in a special message after the body has convened, as well as of matters stated in the proclamation. (Cons. 1875, Art. IV, Sec. 55.)

There is no express provision in any of the three constitutions of the state which vests the power of adjournment either in the two houses, or in the Governor; but by implication this power is vested in the two branches of the General Assembly. This power necessarify follows from the clause in each of the several Constitutions providing that neither house shall, without the consent of the other, adjourn for more than three days at any one time, nor to any other place than that in which the two houses may be sitting . (Cons. 1820, Art. III, Sec. 20. Cons, 1845, Art. III, Sec. 20. Cons. 1865, Art. IV, Sec. 22. Cons. 1875, Art. IV, Sec. 23.) -42- 

It is seen that both houses, being in agreement, may adjourn when they see fit; and that neither house, without the consent of the other, can adjourn for longer than three days - In practice, adjournment is brought about by a joint and concurrent resolution of both houses to that effect. Undue prolongation of the sessions of the General Assembly is discouraged, under the present Constitution, by the provisions, already noticed, reducing the salary of members to \$1 per day after 70 days at regular sessions, and after 120 days at revising sessions .

Further, it is a provision of the present Constitution that every adjournment or recess of the General Assembly for more than three days shall be considered as an adjournment sine die. This prevents the legislature from holding adjourned sessions, as had been done under former constitutions. Every adjournment for three days or less is to be construed as not interrupting the session at which such adjournment or recess is taken, but is regarded as continuing the session, for the purpose of giving the members the compensation provided for them . (Cons. 1875, Art. IV, Sec. 22.)

A dissolution of the General Assembly can only take place by the legal expiration of the terms of the members composing it.

In the last two constitutions, provisions are inserted enjolning on each house of the General Assembly open sessions, except in such cases as may require secrecy. Tach house is to decide what cases require secrecy . (Cons. 1865, Art. IV, Sec. 21. Cons. 1875, Art. IV, Sec. 19 .) 

Wo formal openings of the General Assembly are provided for by any of the constitutions of the state, nor are there any provisions for formal closing . There are no constitutional provisions for dissolution or prorogation of the General Assembly by the Executive. Therefore the two houses may separately arrange their openings and closings at their own aiscretion, under the power given them to conduct their internal organization.

Under the proposed constitution of 1845 the length $\circ f$ the sessions of the General Assembly was limited to 60 days; but this provision never became the law of the state, the only provisions to this effect being those as to compensation. (Cons. 1845, Art. III, Sec. 24.) 


8. The Principle of the Quorum in the General Assembly of Missouri.

The first Constitution fixed the quorum capable of legislating at a "majority of each house", but provided that a smaller number might adjourn from day to day, and compel the attendance of absent members in such manner and under such penalties as each house might provide.

The legal majority under these provisions was an absolute majority of all the members elected to each house, i.e., legally elected; and this meant one more than one half of such membership. Such a majority might legally undertake legislation. The presence of a working majority was assured by the power conferred upon each house to compel absent members to attend its meetings. Each house might, under its own rules, determine the presence of a quorum.

(Cons. 1820, Art. III, Sec. 17.)

The next Constitution of the State practically reenacted these provisions, the only change being that the legal quorum was stated to be "a majority of the whole number of members of each house". (Cons. 1865, Art. IV, Sec. 18.)

The Constitution of 1875 adopted these provisions without change. (Cons 1875, Art. IV, Sec. 18.) 

9. The Internal Organization of the two Houses of the General Assembly of Missouri .

As a general rule, the different constitutions have vested in each house the power of prescribing and regulating its own internal organization. Thus, as is the case in the Constitution of the United States, and in all state constitutions, they have, in general, the right to elect their own officers, to determine their own rules of discipline and procedure, and to compel the attendance of absent members.

Under the present constitution, these powers are onumerated in Section 17 of Article IV., which deals with the Legislative Department, and as they differ in no material respects from the corresponding provisions of the previous constitutions, they will be quoted in full:

" Each house shall appoint its own officers; shall be sole judge of the qualifications, election and returns of its own members; may determine the rules of its own proceedings, except as herein provided; may arrest and punish by fine, not exceeding three hunared dollars, or imprisonment in a county jail not exceeding ten days, or both, any person not a member, who shall be guilty of disrespect to the house by any disorderly or contemptuous behavior in its presence during its sessions; may punish members for disorderly conduct, and, with the concurrence of two thirds of 

all members elect, may expel a member; but no member shall be expelled a second time for the same offence."

To these general powers as here enumerated, there are limitations imposed by other sections of the different constitutions. The Constitution of 1820 provided that the Iieutenant Governor should be President of the Senate; he held this position ex officio; in committe of the whole he might debate all questions, and in case of a tie vote he cast the deciding vote in the senate, and also on a joint vote of both houses. (Cons. 1820, Art. IV, Sec. 15.)

This section is found in both the subsequent constitutions. (Cons. 1875, Art. V, Sec. 15.)

A further limitation on the powers of the General Assembly in the matter of internal self regulation is the duty imposed on each house to keep a journal of its proceedings, which they must publish from time to time, except such parts thereof as may, in their judgment, require secrecy. Again, at the request of any two members of either house, the yeas and nays on any question must be entered on the journal. (Cons. 1820, Art. IV, Sec. 18.)

This provisions was also edopted in 1865, with the further proviso that whenever the yeas and nays on any question were demanded, the whole list of member should be called, and the names of the absentees noted and published with the journal. This section enables the constituents of any legislator to keep account of the attendance of their representative (Cons. 1865, Art. IF, Sec. 18.) 

All the provisions enumerated above are found in the present constitution. (Cons. 1875, Art. IV, Sec. 42.)

Within this general rule and its limitations each house is at liberty to form all rules for its regulation and procedure that it sees fit. Its powers over its members are well defined. Mo decisions of the Supreme Court have tested how far its powers may extend in the case of persons not members . Certainly it can expel unruly persons, not members, from its meeting place, and send them to jail in its discretion, under the strict letter of the Constitution, notwithstanding the fact that this is a judicial power: Thether the ten days imprisonment provided for outsiders must be during the session of the legislature at which it is imposed is a matter which has not been judicially decided. 

10. The Mode of Legislation in the General Assembly of Missouri .

The successive Constitutions of the state have prescribed in detail the various formalities to be followed in the passage of legislation through the two houses of the General Assembly .

All legislation must be enacted under the title : " Be it enacted by the General Assembly of the state of Missouri." The text of each law must follow this caption. (Cons. 1820, Art; III, Sec. 36. Cons. 1865, Art. IV, Sec. 26). (Cons. 1875, Art. IV, Sec. 24.)

The general principle followed by the different constitutions is that legislation may originate in either house, and be altered, amended, or rejected by the other. (Cons. 1820, Art. III, Sec. 21. Cons. 1865, Art.III, Sec.23.) (Cons. 1875, Art. IV, Sec. 26.)

The draft constitution of 1845 would have changed this rule, by inserting a clause similar to that found in the Constitution of the United States, requiring all revenue bills to originate in the House of Representatives .

$$
\text { (Cons 1845, Art. IV, Sec. 23). }
$$

Fach bill proposed in either house must be read in each house on three successive days, unless two thirds of the house where the bill is depending dispenses with the rule. This was the rule under the first two constitutions, but the present Constitution gives no discretion to either house to 

dispense with the reading. This provision is intended to acquaint legislators with matters upon which they are to vote. (Cons. 1820, Art. III, Sec. 21 . Cons. 1845, Art. III, Sec. 2I) (Cona. 1865, Art. IV, Sec. 18. Cons. 1875, Art. IV, Sec. 26.)

The Constitution of 1820 and the draft constitution of 1845 left to the General Assembly the decision as to what majority was required to pass any bill. The two later Constitutions provided that no bill could become a law unless passed by a majority of all the members elected to each branch of the General Assembly.

(Cons. 1865, Art. IV, Sec. 24. Cons. 1875, Art. IV, Sec. 31). Under all the constitutions of the state it has been required that all bills must be signed by the presiding officer of each house. His signature is not to be affixed until the bill has been finally passed; and without this formality no bill can become a law. (Cons. 1820, Art. III, Sec. 2I; Cons. 1845, Art.III, Sec. 21; Cons. 1865, Art. IV, Sec. 22). The present Constitution treats this matter with greater particularity than any of the previous constitutions . Every bill must be signed by the presiding officer of each house in open session; before such officer shall affix his signature to any bill, he must suspend all business, declare that such bill is to be read, and state that, if no objections are raised, he will sign the same to the end that it may become a law. If no objections are raised, he then signs the bill; this fact is entered upon the journal, and the bill is immediately sent to the other house. When it reaches the other house, $-50-$ 

the presiding officer of that house must immediately suspend all other business, announce the reception of the bill, and the same proceedings must then be observed, in every respect, as in the house in which it was first signed.

If in either house any member objects that any substitution, omission, or insertion has occurred, so that the bill purposed to be signed is not the same in substance and form as when considered and passed by that house, or that any particular clause of this article of the Constitution has been violated in its passage, the objection must be passed on by the house; and if sustained, the presiding officer shall withhold his signature. If the objection is not sustained by the house, any five members may embody such objection in a written protest, under oath and signed by them, against the passage of the bill. When this protest is offered in the house, it must be entered upon the journal; the original protest is to be annexed to the bill and considered by the Governor in connection with his consideration of the bill.

$$
\text { (Cons. 1875, Art. IV, Sec. 37.) }
$$

This section makes for greater security in the passage of legislation. In theory, at least, it insures that the presiding officer of either house shall not sign any bill whose contents he is not aware of . By the provisions requiring all other business to be suspended, and the bill to be finally read, additional opportunity is offerred legislators to become familiar with the final draft of bills which are about to become law by their sanction; and by the provisions regarding objections, all mistakes that may have occurred in the passage 

of any bill may be noticed and corrected. The requirement that all such objections must be presented to the Governor in connection with the bill acts as a check on the legislative power, since it suggests to the executive an exercise of his veto power. These provisions of course greatly limit the power of the General Assembly to make its own rules and regulations.

No bill can become a law unless the vote upon its final passage is taken by yeas and nays, and the names of all members voting for and against it must be entered upon the journal. This provision is common tomany state legislatures. (Cons. 1875, Art. IV, Sec. 3I). The present Constitution provides another rule of procedure which is binding on both houses, in that no bill can be considered for passage unless it has been reported upon by a committee, and printed for the use of the members of each house. The purpose of this clause is obvious, since committee work is necessary to intelligent legislation, and the text of a bill must be before the members of the legislative body before they can decide upon its merits.

$$
\text { (Cons. 1875, Art. IV, Sec. 27). }
$$

Since the adoption of the Constitution of 1865, no law passed by the General Assembly can contain more than one subject, which must be expressed in the title of the bill. A law containing a subject not expressed in the title was void as to the subject not so expressed.

$$
\begin{aligned}
& \text { (Cons. 1865, Art. IV, Sec. 32). } \\
& -52-
\end{aligned}
$$



The draft constitution of 1845 had required unity of subject matter only in special or local legislation.

(Cons. 1845, Art. III, Sec. 34.)

The present Constitution makes an important exception to this rule. General appropriation bills may be passed, embracing the various subjects and accounts for and on account of which moneys are appropriated. This exception makes for expediency in appropriating money for the large number of objects for which each General Assembly must provide.

(Cons. 1875, Art. IV, Sec. 28.)

The first Constitution and the proposed constitution of 1845 left it to the General Assembly to provide all regulations to be followed in regard to the amendment and reenactment of bills. The two later Constitutions have greatIy IImited the legislative power in this respect. The Constitution of 1865 declared that no act should be revived or reenacted by mere reference to its title; and that no act should be amended by striking out designated words, or by striking out certain words and inserting others in lieu thereof - In every case of reenactment or amendment, the act reenacted, or the act or part of an act amended, must have been set forth and published at length, as if it were an original bill . (Cons. 1865, Art. IT, Sec. 25.)

These provisions were clearly intended to prevent the mistakes that might occur through carelessness in the passage of bills. If the methods prohibited by this section were allowed to obtain, bills might inadvertently be passed which 

were never intended to become laws. These precalitions

were adopted by the constitution of 1875 .

(Cons. 1875, Art. IV, Secs. 33 and 34 ).

The present constitution is more specific in its provisions regarding amendments than any previous constitution. No law can be passed except by bill, and no bill can be so amended in its passage through either house as to change its original purpose. All amendments adopted by either house to a bill originating and pending therein must be incorporated with the bill by engrossment, and the bill thus engrossed must be prirted for the use of members before its final passage. (Cons. 1875, Art. IV, Sec. 29). The same procedure is to be followed when a bill which is originated in one house is amended in to other, and is returned to the house in which it originated.

(Cons. 1875, Art. IV, Sec. 30 ).

The Constitution also provides that no amendments to bills originatirg on one house, made by the other, shall be concurred in by the originating house except by a majority vote of the members elected to such house. The same majority is required to adopt a report of a committee of conference, in each house. (Cons. 1875, Art. IV, Sec. 32).

Each house must keep a journal of its proceedings. This journal must be published from time to time, Any member of either house may aemand that the yeas and nays upon any question shall be entered upon the journal of his house; when this demand is made, the whole list of members must be called, and the names of absentees noted and published with 

the journal.

(Cons. 1875, Art. IV, Sec. 42.)

The procedure to be followed in passing joint resolutions has been prescribed by the various constitutions. The Constitution of 1820 required that every resolution to which the concurrence of both houses was necessary, except in cases of adjournment, must be presented to the Governor, and must, before taking effect, be proceeded on in the same manner as in case of bills. This meant that all the formalities of reading, voting, and signing must be comlied with.

$$
\text { (Cons. 1820, Art. IV, Sec. II). }
$$

This requirement was adopted by the draft constitution and the Constitution of 1865, without change.

(Cons. 1845, Art. IV, Sec. 11. Cons. 1865, Art. T, Sec. 10). The present Constitution enlarges the exceptions to this rule to include questions of going into joint session and of amending the Constitution, as well as of adjournment. A proviso is inserted to the effect that no resolution shall operate to amend, repeal, alter or extend any law. The purpose of the proviso is to prevent legislation being passed in any other than the modes prescribed by the Constitution.

The last steps in the process of legislation is found in the provisions of the various constitutions of the state requiring all bills to be presented to the Governor for his approval or rejection. The procedure to be observed in the various situations which may arise after this has been done has been prescribed by constitutional provisions.

The Constitution of 1820 required every bill which had $-55-$ 

been passed by both houses of the legislature to be presented to the Governor before it could become a law. If he approved of the bill, he must sign it; if not, he returned it, with his objections, to the house in which it originated. The house entered the objections of the Governor at large upon its minutes, and proceeded to reconsider the bill. If, after this reconsideration, a majority of all the members elected to that house agreed to pass the bill, it was sent, with the objections, to the other house, and in like manner considered by it. If approved by a majority of all the members elected to that house, the bill became a law notwithstanding the objections of the Governor. In all such cases the votes of members were to be taken by yeas and nays, and the names of members voting: for and against the bill entered upon the journal of the respective houses. (Cons. 1820, Art. IV, Sec. 10).

The above procedure was to be followed in passing a bill over the Governor's veto. It is evident that the veto power of the Governor of Missouri, under the Constitution of 1820, was not absolute; nor has it been made so by any subsequent Constitution of the State.

It was further provided by the section referred to above, that if any bill was not returned by the Governor, within ten days, sundays excepted, after it was presented to him, the bill became a law as if he had signed it; unless the General Assembly, by its adjournment, had prevented the return of the bill . This is commonly known as the Governor's "pocket veto", and is the strongest legislative power 

possessed by the Executive. If any bill was presented to the Governor under the circumstances enumerated above, the veto of the Governor upon that particular bill was of as much force as if made absolute by the Constitution.

These provisions were in substance incorporated in the draft constitution and the Constitution of 1865 . Under the former instrument, if a bill was not returned in four days, instead of ten, as originally, it became a law. The Constitution of 1865 varied the regulations slightly, by providing that a bill which could not be returned by the Governor on account of the adjournment of the General Assembly should not become a law, unleas the Governor, within ten days, (Sundays excepted) after such adournment, should sign and deposit it in the office of the secretary of state, in which case the bill became a law as if signed by the Governor during the session of the General Assembly. (Cons. 1865, Art. V, Sec. 9).

The Constitution of 1875 contains more detailed provisions regulating this matter than any of the previous constitutions, and consequently imposes the greatest limitations upon the powers of the General Assembly in this respect.

Every bill which has been signed by the presiding officer of both houses, must be presented to the Governor, by the Chief Clerk of the House of Representatives, if the bill originated in the House; and by the Secretary of the Senate, if the bill originated in that body. The presentation must be by this officer in person, and on the same day that the bill is signed in the house in which it originated. 

If the bill is returned by the Governor vith his approwal, within ten days, it becomes a law, unless it be in violation of some provision of the constitution. (Art. IV, Sec. 38). The formalities to be observed by the two houses when the Governor returns a bill with his objections are substantially the same as those prescribed by the const tution of 1865 . However, the majority necessary to pass a bill over the Governor's veto was increased from an absolute majority, as under the two previous Constitutions, to two thirds majority of all the members elected to each house. (Art. IV, Sec. 39, 1875). A new provision declares the procedure to be followed by the General Assembly when the Governor fails to return or approve a bill. When this occurs, both houses of the General Assembly may, by a joint resolution reciting the bill at length, and the fallure of the Governor to slgn or return it, direct the secretary of state to enroll the bill as an authentic act, in the archives of the state. When this procedure is complied with, such enrollment has the effect of an approval by the Governor. Such joint resolutions cannot be submitted to the Governor for his approval. (1875, Art. IV, sec, 40). If the General Assembly finally adjourns within 10 days after any bill has been presented to the Governor for his approval or disapproval, the Governor may, within 30 days thereafter, return the bill to the office of the secretary of state, with his approval, or reasons for his disapproval. The same regulation applies to all joint resolutions to which the concurrence of the Governor is necessary .

(Cons. 1875, Art. V, Sec. 12). 

Under the present Constitution, the Governor is given an authority not possessed by the Rxecutive under any previous Constitution, and in fact granted to the Governor of but a few States in the Union. If any bill presented to him contains several items of appropriation of money, he may object to one or more items while approving other portions of the bill. When such a bill is presented to him, he must affix to the bill, at the time of signing it, a statement of the items to which he objects, and such items shall not take effect. (Cons. 1875, Art. V, Sec. 13.)

It is evident that the effect of this provision is to give the Governor a suspensive veto power over items of appropriation to which he.objects, without at the same time extending the veto to the entire bill. If the General Assembly is in session, a copy of the Governor's statement must be transmitted to the House in which the bill originated, and the items objected to must be given a consideration separate from the remainder of the bill. If the legislature is not in session, the statement must be transmitted to the office of the secretary of state within thirty days, together with the Governor's approval, or reasons for disapproval.

The final provision prescribed by the Constitution on the complicated subject of legislative procedure fixes the time when laws passed by the General Assembly shall take effect. No law, except the general appropriation act, shall go into force until 90 days after the adjournment of the session at which it was enacted, unless in case of an emergency, 

(which emergency must be expressed in the preamble or in the body of the act), the General Assembly shall, by a vote of two thirds of all the members elected to each house, direct that such act shall take effect sooner.

(Cons. 1875, Art. IV, Sec. 36).

The matter was not regulated by previous constitutions. From the foregoing discussion, it is evident that the several constitutions of the state have limited very materially the discretion of the General Assembly in providing the procedure to be followed in the enactment of legislation. These limitations have been increased by each successive constitution, and reached their height in the constitution of 1875.

While some constitutional restrictions on the subject are wise, it is questionable whether so much detail in legislative procedure is advisable, as instances have occurred in the State where salutary bills have failed to become laws, by becoming entangled in innumerable convolutions of red tape.

Further details of the legislative process, such as the conditions under which an individual member may propose a bill, resolution, etc., the reports upon bills, their order upon the calendar, the rules of debate, committe work, and other like matters, are left to be provided by the two houses, under their power to prescribe their own rules of parliamentary procedure. 



\section{PART II.}

POWERS.

CH $/$ PTER 1. Introduction .

The legislature of Missouri, like the legislatures of the other states in the Union, differs from the Congress of the United States in that it does not exercise specific delegated powers, but has a general residuary authority .

This general power of the legislature is limited by provisions of the Federal and state constitutions. The Federal Constitution limits this power to the extent that it confers power upon the national government or prohibits it to the states.

The General Assembly possesses all the power of the State except in those instances where the State Constitution has granted power to some other department of government, has denied it to the legislature, or contains itself provisions regulating any matter.

The Constitution of 1820 contained few limitations upon the General Assembly . The Executive and Judicial Departments were not defined in detail, but were left to be regulated by statute. The same was true of the field of local government. There were few positive prohibitions 

upon the legislative power except those arising from the Bill of Rights. Finally, the Constitution did not contain much matter of positive regulation which would have operated as a restraint upon the power of the General Assembly . This condition was changed under the two later constitutions, in which the limitations assumed great proportions .

These limitations upon the legislative power form so important a factor in a consideration of the powers of the General Assembly under the two later constitutions that it is thought advisable, for the purposes of this paper, to examine separately the powers of the legislature under the Constitutions which have successively been proposed as the fundamental law of the state.

The legislative power will first be examined under the original Constitution, that of 1820 . The extent of the legislative power under the draft constitution of 1845 and the two later adopted Constitutions will be afterward considered. 

CHAPTER 2. Powers of the General Assembly under the Constitution of 1820 .

Keeping in view the theory of the powers of the General Assembly outlined in the introduction, that it has a general residuary power, it is evident that a definition of these powers will comprise an examination of the limitations imposed by the Constitution, viz., A. The Executive Department . B. The Judicial Department. C. Positive Prohibitions upon Legislation. D. Regulations in the Constitution.

Each of these limitations will be discussed in turn .

\section{A. The Executive Department.}

In establishing this branch of the state government, the Constitution imposed the first important limitation upon the authority of the legislature. The chief executive authority of the state was vested in the Governor; the offices of Attorney General, Lieutenant Governor, Secretary of State, Auditor of Public Accounts, and State Treasurer were also established. In the field of local government, no offices were created except sheriff and coroner in each county. In case of vacancy in any office, the Governor was empowered to appoint a person to fill it, until a successor was duly chosen and qualified. (Cons, 1820, Art.IV) 

All other matters of detail in regard to the organization of this department were left to be regulated by the General Assembly .

B. The Judicial Department.

The Constitution vested the judicial power of the state in a Supreme Court, a Chancellor, and Circuit Courts. (Cons. 1820, Art. IV, Secs. 1,11,12.)

The furisduction of these courts, the tenure and term of judges, the court circuits and sessions were regulated by the Constitution: but power was reserved to the General Assembly to provide that the sessions of the supreme Court should be held in one place only, instead of in the circuits established by the Constitution.

All courts were to appoint their own clerks - A sufficient number of justices of the peace were to be established in the counties of the state as they became necessary - The establishment of inferior courts, and all other matters of regulation in regard to the judicial system not mentioned in the Constitution, remained within the power of the General AssembIy. (Cons. 1820, Article. . .)

C. Positive Prohibitions upon Legislation.

Under the terms of the Missouri Compromise, the State entered the Union as a slave holding state . Consequently it was to be expected that the first Constitution would contain provisions regulating slavery. In these provisions are 

found the first express limitations upon the power of the Gen eral Assembly .

In two classes of cases the legislature was powerless: 1- It could not pass laws for the emancipation of slaves without the consent of their owners, or without paying them, before such emancipation, the value of the slaves emancipated. This provision was simply a constitutional recognition of the status of slaves as private property .

2- It could not prevent bona fide emigrants to the state, or actual settlers within its boundaries, from bringing from any of the United States, or from the Territories, into the state, any persons who might be regarded as slaves in the state or Territory from which they were brought, so long as such persons were allowed to be held as slaves by the laws of Missouri.

$$
\text { (Cons. 1820, Art. III, Sec. 26.) }
$$

A further express limitation upon the legislative power was contained in the provisions regulating the size of counties. No county established at the time of the adoption of the Constitution, could ever be reduced in the establishment of new counties to less than 20 miles square; nor could any county be established thereafter containing less than 400 square miles. (Cons. 1820, Art. III, Sec. 34.)

A restraint was imposed upon the legislative power in establishing banks. While the General Assembly might incorporate one banking company, not more than one could be in operation at the same time. The bank so incorporated might have any number of branches up to five; but only one branch could 

be established at any one session of the General Assembly. (Cons. 1820, Art. VII, Sec. 1.)

The above comprise all the positive limitations imposed upon the legislative power by the Constitution of 1820, exclusive of the Bill of Rights, which it is not within the scope of this paper to discuss.

\section{Regulations in the Constitution.}

The Constitution provided for a military organization within the State. The Governor was made commander in chief of the army and navy of the state, except when called into the service of the United States . The office of Adjutant General was created, to be filled by appointment by the Governor . Field and staff officers were to be elected by the body of troops when organized, following a plan outlined in the Constitution. (Cons. 1820, Article IX.)

Slavery, also, was to a small extent made the subject of positive regulations in the Constitution, several classes of cases being enumerated in which the General Assembly was to pass laws as expeditiously as possible. These laws were to prohibit free negroes and mulattos from settling in the State; to prohibit slaves who had committed crimes elsewhere, or who had been illegally brought within the jurisdiction of the United States, from being brought into the state; and to prevent the introduction of slaves for purposes of speculation or commerce. (Cons. 1820, Art. III, Sec. 26.) Several provisions were inserted which constituted, in effect, a bill of rights for the slave. -66- 

The Constitution regulated the matter of a seat of government for the then new state. Commissioners were to be chosen by the General Assembly, who were to select the site. One commissioner was to be chosen from the midale portion of the state, and one from each of the extreme portions. The site was to be chosen from the land granted to the state by the Federal Government for this purpose, or, if this land was not suitable, the General Assembly could authorize the commissioners to purchase a site of 640 acres elsewhere. In no event could the site chosen be elsewhere than on the banks of the Missouri River, and within 40 miles of the mouth of the Osage River. (Cons. 1820, Art. XI.)

The important subject of education was regulated, in general terms, by the Constitution. At the time of the admission of the State into the Union, the l6th. section lands in each township were donated to the state by the Federal Government for school purposes. The funds arising from this source were to be preserved and invested by the General Assemb1y, and applied in conformity to the terms of the grant. One school or more was to be established in each township, as soon as necessary, where the poor were to be taught free.

$$
\text { (Cons. 1820, Art. VI, Sec. 1.) }
$$

The proceeds of the funds arising from the lands donated by the Federal Government to the state for the benefit of a seminary of learning were to be likewise preserved, and applied by the General Assembly for the purpose mentioned.

(Cons. 1820, Art. VI, Sec. 2.) 

CHAPTER 3 . Powers of the General Assembly under the Proposed Constitution of 1845 .

While a number of amendments to the original Constitution were adopted after 1820 and previous to the date of the draft constitution of 1845, but one of these affected the powers of the General Assembly . This amendment, ratified in 1822, abolished the office of Chancellor, reserving power to the General Assembly to establish a court or courts of chancery when deemed advisable. (Laws Mo., 1848, page 20.)

The Constitutional Convention which convened in Missouri in 1845 prepared a draft constitution for the state, which was rejected by the people when submitted to them at election.

In tracing the historical development of the powers of the General Assembly of Missouri, however, it is necessary to examine the legislative power under the terms of this proposed constitution as well as under the constitutions which were adopted.

The powers of the General Assembly here, following the theory outlined in the discussion of the legislative power under the first Constitution, will be defined by a consideration of the four general limitations established in the Constitution; viz., A. The Executive Department. B. The Judicial Department . C. Positive Prohibitions upon Legislation. D. Regulations in the Constitution. 



\section{A. The Executive Department .}

The provisions of the proposed constitution in regard to the organization of the Executive Department closely followed those of the Constitution of 1820, and imposed few aditional limitations upon the legislative power . The offices established by that instrument were continued, and only one new office, that of superintendent of Public Schools, was created . (Cons. 1845, Art. VI, Sec. 2.)

No new matters of detail relating to executive organization were introduced, and the powers of the General Assembly remained in this respect unimpaired.

\section{B. The Judicial Department .}

The draft constitution vested the judicial power of the State in a Supreme Court, Circuit Courts, County Courts, Justices of the Peace, and such tribunals inferior to the Circuit Court as the General Assembly might establish . It is evident that this enumeration did not encroach on the legislative power, as no courts were created that were not authorized by the Constitution of 1820 . (Cons. 1845, Art. V, Sec.1). The regulation established by the original constitution in regard to court circuits was reenacted. The tenure and term of judges, and the filling of vacancies was also regulated by the constitution.

The jurisdiction, powers, and judges of the supreme Court were given a more detailed treatment than had been 

accorded to these subjects in the first Constitution. The sessions of the Supreme Court were to be held at the seat of government, until otherwise directed by law .

The tenure and term of the various court clerks were regu lated in detail. Judicial officers and clerks were to be elected on a day different from that of any other election in the state.

From these enactments it is seen that the proposed constitution contained a more detailed organization of the judicial system than did the Constitution of 1820, and to this extent would have abridged the power of the General Assembly. (Cons. 1845, Article V.)

\section{Positive Prohibitions upon Iegislation.}

The draft constitution reenacted the provisions of the original Constitution enumerating the cases in which the General Assembly was forbidden to pass laws in regard to slavery . (Cons. 1845, Art. III, Sec. 26.)

The first limitation upon the power of the legislature to create a state debt is found in this instrument. The General Assembly was forbidden to pass any law creating a debt which would cause the entire debt of the state, created under that constitution, to exceed at any one time the sum of $\$ 25,000$, except in cases of war, invasion, or rebellion. But a proposition to create a debt for any specified purpose might be submitted to the people at election, and if ratified, would be of full force and effect. No more than one such 

proposition could be submitted at any one session of the General Assembly. (Cons. 1845, Art. III, Sec. 31.)

Another limitation upon the legislative power was a clause absolutely prohibiting legislative divorces in all cases . (Cons. 1845, Art. III, Sec. 32.)

In regulating the size of counties, the draft constitution slightly modified the requirements of the first Constitution. No existing county could be reduced, in establishing new counties, to less than $20 \mathrm{mlles}$ square; and no new county could be established containing less than 500 square miles. 400 square miles had been the minimum under the Constitution of 1820 . The draft constitution further provided that no new county could be organized so as to entitle it to separate representation, unless the number of free white inhabitants therein at the time of its establishment should be equal to two thirds of the then existing ratio of representation. (Cons. 1845, Art. III, Sec. 4I).

A restraint was placed upnn the legislative power in the matter of establishing banks. No corporate body could be renewed, extended, or created with the privelege of issuing or making any negotiable instrument, or of issuing the commercial paper of any other corporate body, to circulate as money. (Cons; 1845, Art. VII, Sec. 1.)

The creation of other corporations was also restricted. No corporate body, except for politioal or municipal purposes, or for purposes of education or charity, could be created by the General Assembly, unless the right to repeal or amend its 

charter was reserved to the legislature in every act creating such a corporation. And no corporation could be created to exist for a longer period than 20 years . (Cons. 1845, Art. VIII.)

No lottery could every be authorized by the state, and the buying and selling of lottery tickets within the state was prohibited. (Cons. 1845, Art. VIII, Sec. 3.)

The state was forbidden to be a stockholder in any corporation. Neither the school funds, nor any other funds which the state might hold in trust for her citizens at any time, could be placed in or loaned to any bank or other corporation. (Cons. 1845, Art. VIII.)

D. Regulations in the Constitution.

The military organization of the State, with the limitation that the Governor should be commander in chief of the state troops, was left to the regulation of the General Assembly . The first Constitution had attempted to outline this organization with some detail.

$$
\text { (Cons. 1845, Art. III, Sec. 33.) }
$$

The regulations in regard to slavery which had appeared in the Constitution of 1820 were reenacted without change of language - (Eons. 1845, Art. III, Secs. 27 and 28.)

Education received more attention in the draft constitution than it had in the earlier instrument. The same disposition was made of the common school and seminary lands as had been done in 1820; and in adition it was provided that a system of state public schools should be established by the 

legislature. Such schools were to be maintained by taxation on property, or by other taxes. No distinctions could be made in such schools for or against any religious denomination, and the English language was to be taught. A school fund was established, and the several sources from which it was to be derived were enumerated . This fund was to be appropriated by the General Assembly for educational purposes . The office of Superintendent of Public Schools was established. lCons 1845, Art. VI.

The Constitution permanently established the seat of government at Jefferson City, in the county of Cole. (Cons. 1845, Art. VII.)

Stockholders in private corporations were made liable, by a constitutional provision, for all the debts and liabilities of the corporation. (Cons. 1845, Art. VIII, Sec.2.)

The General Assembly was to provide, by suitable legislation, for the sale of all or part of the stock owned by the state in the Bank of Missouri . The plan to be followed in the event that part only of the stock was sold was outlined in the constitution.

Altho the draft constitution of 1845 never became the organic law of the state,several changes suggested by its provisions were made part of the Constitution of 1820 by constitutional amendments.

The power of the legislature to grant divorces was 

taken away by an amendment adopted in 1853. It was enacted that divorces could be granted only by the courts, under the authority of laws of general application.

(Laws of Missouri, 1853, page 3.)

The requirements of the Constitution as to the creation of new counties were slightly modified and adopted by an amendment ratified in 1851. No county could be oreated with an area of less than 400 miles square; nor could any county be created and entitled to separate representation in the lower house of the General Assembly unless it possessed a number of permanent free white inhabitants equal to three fourths of the existing ratio of representation.

(Laws of Missouri, 1851, page 53.)

The regulations of the first Constitution in regard to banks were materially changed by an amendment proposed in 1855 and adopted in 1856. The General Assembly was no longer Iimited to the establishment of one bank, but might incorporate as many banks, up to ten, as the interests of the state demanded; but every bank so established must have been based upon a "private special capital", and made liable to redeem its issues in gold and silver . The aggregate amount of capital invested could never exceed 20 millions of dollars. (Irams of Missour1, 1855, page 4, ptoposed.) (Laws of Missour1, 1856, page 6, adopted.)

In 1858 an amendment was adopted which limited the creation of a state debt. The public indebtedness of the State, incurred in any manner whatsoever, for purposes of 

internal improvement, could never exceed $\$ 30,000,000$. The General Assembly was positively forbidden to create any state liability beyond this amount, except to repel invasion, or to suppress insurrection or civil war.

(Laws of Missouri, 1858-1859, page 3.)

The office of Register of Iands was created, and added to the organization of the Executive Department by a further amendment of 1851. (Laws of Missouri, 1851, page 47.)

From a consideration of the matters embraced in the constitution of 1820 and its amendments, it is noted that the residuary authority of the General Assembly remains, to a great degree, unimpaired. Both the Constitution of 1820 and the proposed constitution of 1845 contained, in general, only matters of a fundamental nature. We find this condition materially changed by the enactments of the two later Constitutions of the state, which will now be examined in the order of their adoption. 

Chapter 4 . Powers of the General Assembly under the Constitution of 1865 .

The Constitution of the State of Missouri which was adopted in 1865 is, in many respects, the most interesting of the State's Constitutions. Adopted at the close of the Civil War, its provisions reflect much of the disorganized condition which existed in the affairs of the state at that time, as well as the bitter political feeling which actuated the framers of the instrument.

On account of the difference in sympathy which existed among the people of the state during the Civil War, between those who had stood for the preservation of the Union, and the adherents and sympathizers of Secession, a chaotic condition existed, at the close of that struggle, in the internal affairs and government of the State. In 1865 a Constitutional Convention convened in the state and adopted a constitution thought to be suited to the problems which confronted the people. In this Constitutional convention the loyal adherents of the Union overwhelmingly predominated; and it was only natural that the Constitution which they drafted should contain many provisions which were radical and political, aimed at that portion of the people of the state who had sympathized with the South during the late War.

In discussing the powers of the General Assembly under this Constitution, these provisions deserve particular notice. 

Foremost among these was the Article in the Constitution which regulated the suffrage, and prescribed the qualifications of voters. (Constitution 1865, Article II.)

These provisions, which form an important chapter in the political history of the State, were discussed at length in a previous section of this paper. (See "The Suffrage from which the Legislature Proceeds", Part I, Chapter 2, page 2. ). This Article imposed a most important limitation on the powers of the General Assembly, since it was powerless to change or modify the qualifications enumerated in the Constitution.

The remaining provisions of the Constitution of 1865 which affected the powers of the General Assembly will be discussed according to the outline followed in considering the previous Constitutions, viz., A., The Executive Department . B., The Judicial Deprrtment . C., Positive Prohibitions on Legislation. D., Regulation in the Constitution.

\section{A. The Executive Department .}

In all materisl respects, the constitution of 1865 , in defining the organization of the Executive Department, left unchanged the provisions of both the Constitution of 1820 and the draft constitution of 1845. The duties and powers of the Governor were enumerated somewhat more in detail. The conditions under which he might exercise his power of granting reprieves and pardons were prescribed. The succession of the Governor, in case the office should become vacant from death, removal, resignation, or other cause, was further 

enumerated than in the previous constitutions.

The offices of Iieutenant Governor, State Auditor,

State Treasurer, and Attorney General were continued, and the qualifications for each prescribed by the Constitution.

The office of Register of Lands was to be continued until the General Assembly should abolish it.

As under the original constitution, the only county offices created were those of sheriff and coroner. (Cons. 1865, Article V.)

B. The Judicial Department.

An important change was made in the judicial system of the State by the erection of District Courts, which shared the judicial power of the state with the Supreme and Circuit Courts, and the inferior tribunals which the General Assembly was authorized to erect. The State was divided into five districts, each district comprising at least three circuits, and in each such district a District Court was erected. The Circuit Judges in each district composed the District Court, and exercised, within the District, original jurisdiction with the Supreme Court, and appellate jurisdiction from the Circuit and other inferior courts of record.

No important chenges were made in regard to the organization and circuits of the supreme and circuit courts, but detailed provisions were inserted providing for the filling of vacancies and deciding election contests.

When the judges of the supreme court could not decide on 

a judgment, the perties to the cuse might choose some person, learned in the law, to sit with them and give the casting vote. On certain solemn occassions, when requested to do so by the General Assembly, the supreme Curt was required to give its opinion on certain constitutional questions.

Inferior courts and justices of the peace in each county were to be established by the General Assembly, as under the previous constitutions. The General Assembly retained its power of impeaching and removing the judges of the various courts. The Supreme and District Courts appointed their own clerks, but all other clerks of courts held by elective tenure. (The draft constitution of 1845 had provided that court clerks and judges were to be elected on a day different from that of any other election in the state.) The amount which any court clerk could retain as fees, after paying deputies, was limited to $\$ 2500$ per jear.

It will be observed that the Constitution of 1865 contained more detailed provisions in regard to the judicial system than either of the two earlier constitutions. These details are, of course, limitations on the legislative power.

(Constitution 1865, Article VI.)

c. Positive Prohibitions on Legislation.

Positive limitations on the legislative power were numerous in the Constitution of 1865, in sharp contrast to the Constitution of 1820 and the draft constitution. These prohibitions are mainly found in the provisions forbidaing the passage of local and special legislation, and were designed 

to prevent the lack of uniformity and legislative abuses which had crept in under a system where it was easy for private interests to obtain desired legislation.

The General Assembly could not, in the following cases, pass local or special laws:

Laws divorcing any named persons, declaring any named minor of age, or authorizing any named minor to sell, lease, or incumber his or her property, or laws providing for the sale of the real estate of any person under legal disability. Nor could it authorize any named company to lay railroad tracks in any city or town, or exempt the property of any named person from taxation. The time for the assessment or collection of taxes could not be extended by special act, nor could any assessor or collector be otherwise relieved fron the due performance of his duties. No special act could be passed legalizing. except as against the state, the unauthorized or invalid acts of any officer, nor giving effect to invalid or informal deeds or wills. No special act could be passed locating or vacating streets or alleys in any city or town, or establishing or altering roads or bridges. (Cons. 1865, Art. IV, Sec. 27.)

No corporation could be oreated by special act, except for municipal purposes; but corporations might be formed under general laws. No municipal corjoration, except cities, could be created by special act; nor could any city be incorporated with less than 5,000 permanent inhabitants, and without a direct vote by the people of the ofty in favor of such incorporation.

No bank could be created to issue bills, notes, or other commercial paper to circulat as money. No law could be passed 



\section{$\gamma$}

reviving or reencating any law creting any private corporation, where an organization had not taken place within one year after the act took effect, or within the time prescribed for the corporation to commence business. (Cons. 1865, Art. VIII, Sec,5)

No special act whatever could be passed in any case where a general act could be made to serve the purpose.

The General Ass mbly was absolutely forbidden to make compensation for emancipated slaves . (Cons. 1865, Art. IV, 29.)

The provisions of the draft constitution prohibiting the licensing of lotteries within the state were reenacted.

No county site could be removed by the legislature, unless two thirds of the qualified voters of the county, at a general election, should vote in favor of the proposed removal. This provision insured a greater degree of local self government in this respect than had been provided for under the firat Constitution. The limitations upon the legislative power as to the size of counties, proposed by the draft constitution of 1845, were adopted in the Constitution of 1865.

(Cons. 1865, Art. IV, Secs. 30 and 31.)

The credit of the State could never be loaned or given in ald of any person, association, or corporation; nor could the state ever become a stockholder in any such association or corporation, except for the sole purpose of securing loans theretofore extended by the state to rajlroad cor orations. (Cons. 1865, Art. XI, Sec. 13.)

The significsnce of this provision is apparent when it is remembered that during the decade beginning with the year 1850 the State had extensively loaned its credit to railroad cor- 

porations, to encourage the building of railroads within the State. Several of these roads were never finished by the companies which had undertaken to construct them, and the state lost largely through the transactions. Finally, in order to secure itself against further losses, it was compelled to foreclose its liens on the roads to which it had advanced its credit. By a further provision in the Constitution of 1865, the General Assembly was forbidien to release the liens so held by the State. (Cons. 1865, Art. XI, Sec. 15.)

Nor could the legislature authorize any county, city, or town in the state to become a stockholder in or to loan its credit to any company or corporation, unless two thirds of the qualified voters of such local subdivision, should cast their votes in favor of such transaction. This provision reflects the period of the State's history when the counties of the state also had bonded themselves to encourage the building of railroads, These bond issues ended in financial dissome of

aster to the counties making them. (Cons. 1865, Art. XI, 14.)

All discretion wis taken from the General Assembly in allowing exemptions from taxation. No property, real or personal could be exempted, except that used exclusively for school purposes, that belonging to the United states, to the State of Missouri, or to the counties or municipal corporations within the state. (Cons. 1865, Art. XI, Sec. 16.)

The above provisions comprised the positive prohibitions on the exercise of the legislative power which were contained in the Constitution of 1865. These provisions afforded a nucleus about which the limitations in the constitution of 

1875, which were more numerous than in any other constitution of the state, were constructed.

D. Regulations in the Constitution.

Education was treated at greater length by the Constitution of 1865 than had been the case in either the original constitution or the draft constitution of 1845 .

All schools in the public school system of the state were to be free; separate schools might be established for children of African Descent . The control of the educational system was vested in a Board of Education, of which the State Superintendent of Education was president. The Sec retary of State and Attorney General were made ex officio members of this board.

The Constitution provided for the continuance of the State University, to be maintained from the school fund. Departments for instruction in Teaching, Agriculture, and Natural Science were to be maintained.

The school fund of the state was established by the Constitution, and the various sources from which it was to be derived were enumerated. No part of the fund could ever be invested in the stock of any state, county, or corporation. No township or school district could participate in this fund unless it had maintained a free school for at least three months in the year; and if the school fund of the state was not sufficient to maintain a free school for four months in the year, in each school district, the General Assembly might provide, by taxation, for the deficiency. 

The General Assembly might, in its discretion, pass a compulsory education law, compelling all persons between the ages of 5 and 18 years to attend school for a term equivalent to 16 months, unless otherwise educated.

Finally, the General Assembly was to reduce the school fund to money, so far as it was possible to do so without interfering with vested rights, and in distributing this fund among the different districts entitled to participate therein, might take into account the amount of any city or county funds, and make such a distribution as would equalize the amount for common schools throughout the state.

$$
\text { (Constitution 1865, Article IX.) }
$$

The organization of the military system of the state was left to the General Assembly . All able bodied citizens of the State, and all persons who had declared their intention of becoming citizens, were made liable to military duty . Each company and regiment elected its own officers, or upon a failure to do so, they were appointed.by the Governor. There could be no officer above the rank of Brigadier General, and only one of that rank. (Cons. 1865, Art. X, Sec. 1.)

Corporations were regulated mainly by the prohibitory provisions which have been noticed above in discussing the prohibitions on legislation. All stockholders in private corporations were made additionally liable to creditors in an amount equal to the value of their stock.

The General Assembly was to pass laws permitting all banks in the State to reorganize as National Banks, and to provide for the sale of the stock owmed by the state in the Bank of Missouri . (Cons. 1865, Art. VIII.9. 

The right of a change of venue for persons indicted for felonies was recognized by the Constitution, and the General Assembly was to provide laws allowing such changes when from prejudice or other causes an impartial trial could not be secured in the county where the crime was committed. 

Chapter 5.

Powers of the General Assembly under the Constitution of 1875.

The Constitution of Missouri which was adopted by the people in 1875 is by far the most comprehensive instrument that has served as the fundamental law of the state.

The distrust which was felt by the people of the state for the legislature at the time of the adoption of the Constitution is evidenced by numerous provisions limiting the exercise of the legislative power. These provisions, / together with others regulating certain matters, constitute the greater part of the Constitution.

Many matters which should have been left to statutory regulation were incorporated in the Constitution. This fact has greatly contributed to the demand, which is growing in the state, for a new Constitution.

The powers of the General Assembly under the present Constitution will be considered, as under former constitutions, according to the following outline, viz.,

A. The Executive Department - B. The Judicial Department. C. Positive Prohibitions on Iegislation. D. Regulations in the Constitution.

A. The Executive Department .

The organization of the Executive Department provided by the present Constitution slightly changes the organization 

established by the Constitution of 1865. All officers of as under the Constitution of 1865,

the department, except the Iieutenant Governor, must reside at the seat of government, and keep their books and papers there.

(Cons. 1875, Art. V, Sec. 1).

The State Board of Equalization was established, consisting of the Governor, Auditor, Treasurer, Attorney General and Secretary of state. Their duties were declared to be to equalize and adjust the valuation of real and personal property between the different counties in the state.

(Cons. 1875, Art. X, Sec. 18).

The powers of the Governor remain practically the same as under the previous Constitution. His military powers are slightly increased, since he may call out the militia to execute the laws, and repel insurrection and rebellion. (Cons. 1875, Art. V, Sec. 7.)

Hiis duties are increased by provisions requiring him to give the General Assembly information, at the close of his term, of the condition of the state; he must account to the legislature for all moneys paid out by him from any funds subject to his orders, and at the beginning of each regular session, present to the legislative body estimates of the amount of money to be raised by taxation for all purposes. (Cons. 1875, Art. X, Sec. 10).

(The powers of the Governor in regard to the enactment of legislation were considered in a previous portion of this paper . See "The Mode of Iegislation"Part I, page 49.). The Constitution left unchanged the powers and duties of the Iieutenant Governor as established by the Constitu$-87-$ 

tion of 1865, and aid not materially change the qualifications or duties of any other officers of the Legislative Department, except that the Governor and State Treasurer were declared ineligible to succeed themselves.

$$
\text { (Cons. 1875, Art. V, Sec. 2.) }
$$

A provision of the present Constitution, applicable to all executive officers, enjoins upon them the duty of keeping strict account of all moneys, etc., disbursed by them in their official capacity. When demanded, all such officers, and the heads of all state institutions, must report to the Governor the condition of affairs in their respective departments and institutions . No such requirement was made by the Constitution of 1865.

(Cons. 1875, Art. V, Sec. 22.)

As under previous constitutions, the offices of sheriff and coroner were erected in each county of the state. (Cons. 1875, Art. IX, Secs 10 and 11).

B. The Judicial Department.

The Constitution vested the judicial power of the State in the Supreme Court, the St.Iovis Court of Appeals, circuit courts, criminal courts, probate courts, county courts, and municipal corporation courts. This section made important changes in the judicial organization of the State. The increase of litigation accompanying the development of the state demanded a change in the appellate system, which resulted in the establishment of the st. Louis Court 

of Appeals, and later of the Kansas City Court of Appeals.

(Cons. 1875, Art. Vi, Sec.1).

No material changes were made by the Constitution in the organization or jurisdiction of the supreme Court, except that its circuits were abolished, and all sessions of the court are to be held at the seat of government : The jurisdiotion of the Supreme Court was necessarily limited by the provisions which made the decision of the st.Louis Court of Appeals final in certain caser.

Subsequent amendments have, however, materially changed the organization of the Supreme Court. A constitutional amendment which was adopted in 1890 increased the Court from four to seven judges, and divided it into two sections. The first division consists of four judges, and the second division of the remaining judges. Fach division sits separately for the hearing of causes, and the two have concurrnet jurisdiction over all causes in the Court, except that the second division has exclusive jurisdiction in all criminal matters. In certain cases causes which have been heard in one division may be transferred to the Court on banc. The division of business is left to the Court, according to detailed regulations which the Constitution provides. Whenerer, in the opinion of the Court, a speedy aisposition of business justifies it, the divisions may be dispensed with.

$$
\text { (R.S.1899, page 94.) }
$$

The Constitution established the st.Iouis Court of Appeals at St. Louis . It was given jurisdiction coextensive 

with the City and County of st.Louis, and several adjoining counties. In 1884 an amendment to the Constitution was adopted, extending the jurisdiction of the Court to embrace 55 counties in the state, and erecting the Kansas City Court of Appeals, whose jurisdiction included the remaining counties in the state. The Constitution as adopted in 1875, and as amended in 1884 regulated in detail all matters pertaining to the organization and jurisdiction of these courts . The number and qualifications of judges, terms of the courts, and rules of practice to be followed, were all prescribed by constitutional enactment.

$$
\text { (R.S.1899, pages 92, 93, and 94.) }
$$

No new regulations affecting the circuit court system of the State were enacted by the Constitution of 1875 , except that at least two terms of the eircuit court must be held in each county of the state every year, and that each circuit judge must be a resident of the eircuit from which he is elected. (Cons. 1875, Art. VI, Sec. 25.)

Criminal Courts.

The General Assembly can establish no criminal courts, except in counties having a population of more than 50,000. (Cons. 1875, Art. VI, Sec. 31.)

Probate Courts.

Probate courts were to be established by the General Assembly in each county. The Constitution made such courts courts of record, to consist of one judge, holding by elect- 

ive tenure. The organization and jurisdiction of these courts was regulated by the Constitution.

(Cons. 1875, Art. VI, Sec. 34.)

County Courts.

As under the Constitution of 1865, a county court was erected in egch county. The constitution sanctioned the right of the General Assembly to provide that the Probate Juage in each county might be one of the county Judges. This had been permissible under the previous constitution, al though not expressly authorized.

(Cons. 1875, Art. VI, Sec. 36).

Justices of the Peace.

The provisions of the Constitution of 1865, requiring a sufficient number of justices of the peace to be created in each county, were reenacted.

(Cons. 1875, Art. VI, Sec. 37).

Court clerks.

The Suprerne court, and the St. Iouis and Kansas City Courts of Appeals are allowed to appoint their ow clerks. All other clerks of courts of recora are to be elected. Under the terms of the previous Constitution all court clerks in the state held by elective tenure, except the clerks of the supreme and District Courts.

$$
\text { (Cons. 1865, Art. VI, Sec. 22). }
$$

Miscellaneous.

The General Assembly was given the power, by a two- 

thirds vote of the members of each house, to remove any judge from his office, when he is unable to discharge his duties, from inability arising from physical or mental infirmity: but the incumbent sought to be removed must be given notice, and has the right to be heard in his own defence. (Cons. 1875, Art. VI, Sec. 41.)

The Supreme Court may designate what opinions delivered by it may be published at state expense, and no other opinions than those so designated shall be published by the State. All judicial decisions of the state are made free for publication by any person.

(Cons. 1875, Art. VI, Secs. 43 and 44 ).

It is evident from an examination of the Constitution of 1875 and its amendments that the provisions in regard to the judicial department have greatly limited the power of the General Assembly, since the judicial machinery of the State is outlined with much greater particularity than has been the case in any previous constitution. 

c. Positive Prohibitions on Legislation.

At the time the present Constitution of Missouri was adopted, an essentially different condition of affairs confronted the state than had been the case when the previous Constitution had been accepted by the people.

Industrial conditions had not fully recovered from the effects of the recent panic of 1873; the financial affairs of the state were likewise disturbed; and the members of the Constitutional Convention felt that among the principal problems confronting them was the provision of means to curtail the improvident expenditures of the state and local governments, and to safeguard the public credit.

Consequently, many more limitations upon the expenditures of both the state and its local subdivisions were adopted than had been the case in the Constitution of 1865 .

These restrictions, which are of course limitations upon the power of the General Assembly, will be classified and considered in the following order :

A. General Financial Limitations - B. Limitations upon Taxation. C. Other positive prohibitions upon the legislative Power .

A. General Financial Limitations.

(1). Limitations on the state. As had been provided by the Constitution of 1865 , no money could be drawn from the state Treasury except in 

accordance with legal appropriations. The present Constitution goes further, and indicates the order in which appropriations shall be made by the successive General Assemblies of the State . (Cons. 1875, Art. IV, Sec. 43 .)

The Constitution imposes severe limitations upon the $\angle$ power of the General Assembly to contract debt in the name of the State. Except in two enumerated cases it has no power to bind the State by creating debt in any manner whatsoever. The first case in which the General Assembly may contract as State debt is purely formal, being the power to renew existing bonds, when they cannot be paid at maturity out of existing funds. The second case arises when there is a casual deficiency in the revenue of the state, or when an unforeseen emergency occurs. If the amount of revenue to be raised does not exceed $\$ 250,000$, the General Assembly may incur this amount of indebtedness, to be paid in not less than two years from its oreation. If the amount exceeds $\$ 250,000$, the debt or liability may be incurred by the General Assembly, after having first secured the consent of two thirds of the voters voting on the proposition, at an election held for that purpose. The Act which must be ratified by the people must contain a provision for paying the principal and interest of the debt by taxation, the principal to be paid in not less than thirteen years after the creation of the debt. After such a proposition is ratified by the people, the General Assembly is powerless to repeal it . (Cons. 1875, Art. IV, Sec. 44.) 

A new provision so restricted the legislative power that it, could never be exercised to extinguish in any manner the debt due from any corporation or individual to the state or to any of its subdivisions . (Cons. 1875, Art. IV, Sec. 51). A limitation was also imposed upon the power of the General. Assembly in paying the War Debt of the State . No part of this debt can ever paid by the state until all claims arising thereunder have been previously paid to the state by the United States Government .(Cons, 1875, Art. IV, Sec. 52.)

A further limitation upon the financial powers of the General Assembly declares that it has no power to grant, or to authorize any political subdivision of the state to grant to any public officer, servant, or contractor, any extra compensation, after his services have been rendered, or the contract entered into and performed in whole or in part. Nor can any compensation be made to any person for an agreement entered into with him by any officer acting without authority of law . (Cons. 1875, Art. IV, Sec. 48.)

The creation of state Banks, as an exercise of the financial power of the State, was prohibited to the General Assembly . Ho act of the legislature creating banks, except banks of deposit and $d$ iscount, can go into effect until submitted to the people, and ratified by a majority of the votes cast. The state cannot own or be liable for stock in any corporation or association organized for banking purposes. (Cons. 1875, Art. XIII, Secs. 25 and 26.) 

The provisions of the Constitution of 1865 which prohibited the General Assembly from loaning the credit of the state to any individual or association of individuals, or to any corporation, whether municipal or private, and that the state should never become a stockholder in any such corporation, except to secure loans previously made by the state to certain railroads, were reenacted by the present Constitution.

(Cons. 1875, Art. IV, Secs. 45 and 49.)

A limitation not found in any previous constitution pro- hibits the General Assembly from granting any money or thing of value to any individual or corporation, whether municipal or private; but this prohibition is not to be construed to prevent the granting of aid in time of public calamity.

(Cons. 1875, Art. IV, Sec. 46.)

A further prohibition applies to both the General Assembly L and the municipal subdivisions of the state. They are forbidden to appropriate from any public fund any sum in aid of any religious purpose whatsoever, nor can they grant from the public funds any money to aid any educational institution, whether public or private, which is controlled by any religious oreed or denomination. Neither the state or any of its local subdivisions can aid any religious sect or creed by the grant of any real or personal property whatsoever.

(Cons 1875, Art. XI, Sec. 11).

The state lien on certain railroads cannot be released, as was also provided by the Constitution of 1865 .

(Cons. 1875, Art. IV, Sec. 50). 

A. (2). Iimitations on the Subdivisions of the state .

Following the provisions of the Constitution of 1865 , it was enacted that the General Assembly should have no power to authorize any political subdivision of the state to lend its credit or to grant any thing or value to any individual corporation, or associtation, or to become a stockholder in any such corporation or associtation of individuals. This provision, as was noted in discussing the previous Constitution, resulted from the financial disaster which had attended county and city aid to railroad building . A proviso was aded to this section of the Constitution by an amendment adopted in 1892, to the effect that the General Assembly might nevertheless authorize cities, towns, and villages to create a fund for the relief of disabled firemen and their families, such fund to be taken from the revenue of such municipal corporations. (Cons. 1875, Art. IV, Sec. 47.) In adition, a special provision was inserted, consonant with the general prohibition noticed above, to prevent municipal aid to colleges and institutions of learning, whether controlled by the state or not. (Cons. 1875, Art. XI, Sec. 11). No debt whatever, in excess of the revenue for one year, can be incurred by any county or other subdivision, without the consent of two thirds of the voters therein; nor, even with such consent, can the total indebtedness exceed $5 \%$ of the assessed value of the taxable property of the local organ. An exception to this rule was made when it is desired to construct a courthouse or jail in a county. (Cons. 1875, Art. X, Sec.12). 

This section was amended in 1905, (Laws of Missouri, 1905, page 324), so as to allow cities with not less than 2000 nor more than 30,000 population to incur a debt amounting to an additional 5\% of the assessed property valuation for the purpose of woning waterworks and lighting plants . A pending amendment, to be roted upon in November, 1908, provides that any such debt incurred for waterworks and lighting purposes shall not be considered in computing the amount of indebtedness which may be incurred by such corporations for other purposes - (Laws of Missouri, 1907, page 454 ,) A further proposed amendment will allow cities of 100,000 inhabitants and over to become indebted in a larger sum than that allowed by the Constitution, to an amount not exceeding 5\% of their assessed property valuation, for the purpose of constructing subways, when two thirds of the qualified voters of such city vote in favor of the increase. (Laws of Missouri, 1907, page 452.) The repeated amendment of this section shows that it is not adapted to the needs of local government in Missouri at the present time.

B. Iimitations upon Taxation ( (1). By the State.

In considering the limitations imposed upon taxation by $<$ the present Constitution, it is to be noted at the outset that practically no such limitations existed in the Constitution of 1865 . The limits imposed to the taxing power by the present Constitution find their reason in the acts of public officials who, during the early period of railroad building, created 

heavy debts to be borne by the state and its localities. This situation had not reached its crucial stage at the time of the adoption of the Constitution of 1865, and consequently the necessity for such limitations had not arisen. The present Constitution, therefore, imposed greater restrictions upon the power of the legislature in this respect. While the restrictions imposed upon the taxing power in 1875 were undoubtedly wise at that time, and while some restrictions on the rates of taxation should always exist, the state has outgrown the limited rates fixed by the constitution. This is apparent from the repeated amendment which this portion of the Constitution has undergone.

The rate of taxation for state purposes, exclusive of the $L$ tax necessary to pay the bonded indebtedness of the state, was limited to 20 cents on the $\$ 100$ valuation, with a proviso that when the taxable property in the state reached the value of 900 million dollars, the rate was not to exceed 15 cents on the \$100 valuation. (Cons. 1875, Art. X, Sec. 8). This property valuation was reached some years ago.

The Constitution doclared what property in the state should be exempt from taxation, and all other exemptions were declared roid. (Cons. 1875, Art. X, Sec. 7).

The General Assembly was deprived of all power to exempt any municipal corporation from the payment of its share of State taxes; nor can it impose taxes upon the local subdivisions for purely local purposes. (Cons. 1875, Art. X, secs. 9 and 10).

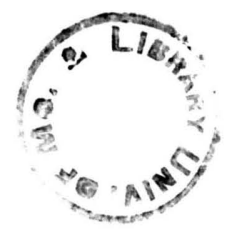



Nor can the legislature exempt corporations or their prop- < erty from taxation under any circunstances.

$$
\text { (Cons. 1875, Art. } \mathrm{X}, \text { Sec. 2). }
$$

(2). Iimitations on Rates for Local Purposes.

In this respect we again find a great contrast between the present constitution and the constitution of 1865. While the latter left the subject entirely to the legislative discretion, the former prescribes in detail the maximum rates of taxation which may bo laid in counties, cities, and school districts. In the case of school districts these rates may be increased to a certain extent, provided the increase is approved by a majority of the taxpayers, voting at an election held for that purpose; but in counties and cities it can only be increased for the erection of public buildings, and the payment of public indebtedness, the amount of which, we have seen, is also strictly limited. (Cons. 1875, Art. X, Sec. 1I). An amendment to this section allowed the counties to levy an additional tax for road purposes; but the amendment was declared unconstitutional on a technical point. (For this amendment see Laws of Missouri, 1903, page 313.) An amendment will be submitted to the voters of the state on November 4th., 1908, allowing both the state and the localities to levy aditional taxes for road purposes. These proposed amendments show the pressing necessity for a thorough revision of the system of taxation to meet the increased demands of the state.

Other Positive Prohibitions upon the Legislative Power in the Constitution of 1875 .

(I) Special Legislation. In regard to the passage of special $-100-$ 

and local legislation by the General Assembly, the constitution imposes many additional restraints. In the constitution of 1865 these limitations were comparatively few in number; but the Constitution of 1875 enumerates no less than 33 cases in which no local or special laws can be passed.

1. Note The Constitution of 1875, Article IV, Section 53, ' provides: "The General Assembly shall not pass any local or special law :

Authorizing the creation, extension, or impairing of liens. Regulating the affairs of counties, cities, twonships, wards or school districts. Changing the names of persons or places. Changing the venue in civil or criminal cases. Authorizing the opening, laying out, altering or maintaining roads, highways, streets, or alleys.

Relating to ferries or bridges, or incorporating ferry or bridgo companies, except for the erection of bridges crossing streams which form boundaries between this and any other state. Vacating roads, town plats, streets, or alleys. Relating to cemeteries, grave yards, or public grounds not of the State.

Authorizing the adoption or legitimation of children.

Locating or changing county seats.

Incorporating cities, towns, or viliages, or changing their charters.

For the opening or conducting of elections, or fixing or changing the places of voting .

Granting divorces.

Frecting new townships, or changing township lines, or the lines of school districts.

Creating offices, or prescribing the powers and duties of officers in counties, cities, townships, election or school districts.

Changing the law of descent or succession.

Regulating the practice or jurisdiction of, or changing the rules $f$ evidence in any judicial proceeding or inquiry before courts, justices of the peace, sheriffs, commissioners, arbitrators or other tribunals, or providing or changing methods for the collection of debts, or the enforcing of judgments, or prescribing the effect of judicial sales of real estate. Regulating the fees or extending the powers and duties of aldermen, justices of the peace, magistrates or constables. Regulating the management of public schools, the building or repairing of school houses, and the raising of money for such purposes. 

Fixing the rates of interest. Affecting the estates of minors, or persons under disability. Remitting fines, penalties, and forfeitures, or refunding moneys legally paid into the treasury.

Exempting money from taxation.

Regulating labor, trade, mining or manufacturing.

Creating corporations, or amending, renewing or explaining the charter thereof.

Granting to any corporation, association, or individual any special or exclusive right, privelege, or immunity, or to any corporation, association, or individual the right to lay down a railroad track.

Declaring any named person of age.

Extending the time for the assessment or collection of taxes, or otherwise relieving any assessor or collector of taxes from the due performance of their official duties, or their securities from liability.

Giving effect to informal or invalid deeds or wills.

Summoning or impaneling grand or petit juries. For limitation of civil actions.

Legalizing the unauthorized or invalid acts of any officer or agent of the state, or of any county or municipality thereof.

In all other cases where a general law can be made applicable, no local or special law shall be enacted; and whether a general law could have been made applicable in any case is hereby declared a judicial question, and as such shall be judicially determined, without regard to any legislative assertion on that subject.

Nor shall the General Assembly indirectly enact such special or local law by the partial repeal of a general law; but laws repealing local or special acts may be passed.

In addition, it was provided that notice of the in- 4 tention to apply for the passage of a special act must be given, and published in the locality where the law is to have application. Evidence of the publication of such notice must be brought before the General Assembly .

(Cons. 1875, Art. IV, Sec. 54.) 

(2) Matters of Local Government .

The power of the legislature in removing county seats was abridged as under the Constitution of 1865 . It was further enacted that no county could be divided without submitting the question to the qualified voters of the county, nor could any county be created whose boundary lines would extend to within ten miles of any existing county seat .

(Cons. 1875, Art. IX, Secs. 2,3, and 4.)

(3) Educational Matters .

The General Assembly is forbidden to invest the school ${ }^{2}$ funds of the State in the bonds or obligations of any other State, or of any corporation, municipal or private; but may invest it in bonds of the State of Missouri, or of the United States . (Cons. 1875, Art. XI, Sec. 9). (Under the Constitution of 1865 , the school funds could only be invested in United States securities). This section was amended in 1902, when the bonded indebtedness of the state was extinguished . This amendment will be treated in another section of this paper •

(4). Railroad Corporations .

The General Assembly was forbidden to pass laws retro- $C$ spective in their operation, or which imposed new liabilities on the people in any part of the state in regard to past transactions, in favor of any railroad or other corporation. Nor can it grant to any corporation or individual the right to construct a street railroad in any city, town or village in the State, without the consent of the people in such locality. (Cons. 1875, Art. XII, Secs. 19 and 20.) 

(5). Miscellaneous .

No lottery can be authorized to operate within the State. This provision also occurred in the previous Constitution. (Cons. 1875, Art. XIV, Sec. 10).

The foregoing provisions constitute the positive limitations imposed upon the exercise of the legislative power by the Constitution of 1875. It is noticeable that they cover almost the entire activity of the legislative department, and that they are far more numerous than in any previous constitution which has served the State.

In the main, these provisions were wise at the time they were adopted. We have noticed several classes of these provisions which should no longer exist, or which should be materially modified, to keep pace with the development of the state. In the light of experience subsequent to the adoption of the Constitution, it seems that the next constitution to be adopted by the State of Missouri should contain far less detailed limitations upon the power of the General Assembly. 

D. Regulations in the Constitution.

The Constitution of 1875, unlike that of 1865, regulated in great detall many matters which should have been left to be dealt with by statute. Since the present Constitution was adopted, it has been often necessary to resort to the expensive and cumbersome process of amendment to adapt the constitutional regulation of certain matters to the changing noeds of the State. Had these matters boen left to the regulation of the General Assembly, incorporating in the Constitution only matters of an organic nature, the necessity for a new constitution at the present time would have been materially lessened .

We will notice, in their general outline, all matters positively regulated by the Constitution. These provisions are, of course, limitations upon the legislative power . (a) - Education . As under the previous constitution of the state, free schools were established. The school age was fixed at between 6 and 20 years. Separate schools must be established for children of African descent.

(Cons. 1875, Art. XI, Secs. 1 and 3.)

In general, the educational system outlined by the Constitution of 1865 was reenacted. The Board of Education was continued, and the government of the State University 

vested in a Board of Curators, consisting of nine members, to be appointed by the Governor.

(Cons. 1875, Art. XI, Secs. 4 and 5.)

The Constitution provided that the public school fund might be invested in the bonds of the state, as well as in United states securities. The Constitution of 1865 had allowed the fund to be invested only in the latter securities. An amendment to the present Constitution, adopted Nov,4,1902, confirmed the certificates of indebtedness of the state to the public school and seminary funds as existing obligations of the state, and provided that as soon as the outstanding indebtedness is extinguished, all moneys accumulating in the State Treasury to the use of these two funds shall be invested in registered county, municipal, or school district bonds of the State of Missouri, of not less than par value.

$$
\text { (Laws of Missouri, 1905, page 318). }
$$

No important changes were made in the sources of the public school fund, the provisions of the Constitution of 1865 being followed in this respect.

$$
\text { (Cons. 1875, Art. XI, Sec. 6.) }
$$

The county school fund was separated from the school fund of the state. Its sources were specified, and the modes in which it may be invested designated.

$$
\text { (Cons. 1875, Art. XI, Sec. 8.) }
$$

Provision was made to supply the needs of the public schools of the state, in case there should be a deficiency in the school fund, making it impossible to maintain a free public school at least four months in the year in each $-106-$ 

school district in the State. The General Assembly was authorized to supply this deficiency by taxation, in accordance with the constitutional regulations on the subject. In no case can there be appropriated annually less than 25 per cent of the state revenue, exclusive of the interest and sinking fund, for the support of free public schools. (Cons. 1875, Art. XI, Sec. 7.)

(b). Matters of Isocal Government.

The Constitution contains an extensive article on counties, cities, and towns, a matter which was scarcely noticed by the Constitution of 1865, with the exception of a few provisions dealing with thedivision of counties and the removal of county seats. These provisions, with slight modifications, were adopted by the present Constitution. (Cons. 1875, Art. IX, Sec. 2.)

In addition, it was enacted that no part of the territory of a county could be stricken off and added to an adjoining county without submitting the question to the voters of the counties immediately interested, and securing the votes of a majority in favor of such change. When any portion of a county is thus stricken off, it is made liable for its proportion of the then existing indebtedness of the county from which it is taken.

(Cons. 1875, Art. IX, Sec. 4.)

If the county to which the adition of territory is made fails to pay this proportion of indebtedness, it is lawful for the county from which the territory was taken to collect 

it by taxation, as it would have done if the change had not been made. (Cons. 1875, Art. IX, Sec. 5.)

Township organization was provided for in any county electing to come within the provisions of such organization. This organization may be discontinued in any county which has adopted it, at the will of the voters therein.

$$
\text { (Cons. 1875, Art. IX, Secs. } 8 \text { and 9.) }
$$

In all counties containing a city of over 100,000 inhabitants, the city and county governments may be consolidated, under the authority of laws enacted by the General Assembly . (Cons. 1875, Art. IX, Sec. 14.)

The Constitution stipulated that the General Assembly should provide, by general laws, for the organization and classification of cities and towns. The number of such classes cannot exceed four, and the powers of cities and towns of each class are to be defined by general laws. under special charter Any city or town existing at the time of the adoption of the Constitution might incorporate under the general laws to be passed by the legislature.

$$
\text { (Cons. 1875, Art. IX; Sec. 7.) }
$$

Certain provisions were made granting greater powers to large cities than they might enjoy under the classification of cities to be provided by the General Assembly . All cities of over 100,000 population are allowed to frame charters for their ow government - Charters so framed must of course be consistent with the Constitution and laws of the state. The Constitution sets forth many of the details 

to be regarded by a city desiring to frame such a charter. Every such charter must provide for a government embracing a mayor and two houses of legislation. It is stipulated that at least one house of the legislative assembly in every such city shall be elected by general ticket.

(Cons. 1875, Art. IX, Secs. ,16, and 17).

Special priveleges are also accorded to the City of st. Louis. It was authorized to extend its boundaries to embrace certain contiguous territory, and empowered to adopt a charter for the government of the city as thus enlarged. The government of the City of St. Louis was separated from that of the county of st. Louis, the residue of which remained a legal county of the state. The charter adopted by the eity may be amended, at intervals of not less than two years. The Constitution prescribed all matters of detail relating to the changed organization of the city, fixed its representation in the General Assembly, and altered its judicial system to meet existing demands . (Cons. 1875, Art. IX, Secs, 20-25 Inc.)

The amount of fees which any county officer may receive in any one year is limited by the Constitution to $\$ 10,000$, exclusive of salaries actually paid to deputies . The details of official reports to be made by such officers were also prescribed. The fees of all county officers must be regulated by general laws, uniform in their operation.

(Cons. 1875, Art. IX, Secs. 12 and 13.) 

The present Constitution imposes a prohibition upon dual office holding in certain municipal subdivisions of the state. In counties or municipalities having more than 200,000 inhabitants, no person can hold a state office and an office in such municipality at the same time; nor can any person fill two municipal offices at the same time, excpet certain minor offices, which are enumerated.

(Cons. 1875, Art. IX, Sec. 18.)

(c). Revenue and Taxation.

The chapter on revenue and taxation composes a most important part of the present Constitution. It consists for the most part of limitations upon the rates of taxation, which have been considered in a previous portion of this paper . All cases where the Constitution positively regulates any matter connected with the taxation system will be noticed here. 1. Organic Financial Rules.

At the outset it was enacted that the taxing power should be exercised by the General Assembly for state purposes, and by the municipal subdivisions of the state for local purposes.. (Cons. 1875, Art. X, Sec. 1.)

Taxes can be collected for public purposes only; uniformity in taxing the same class of subjects within the territorial limits of the authority laying the tax is laid down as the general rule to be follwed in administering the taxation system of the State. All taxes must be levied under the authority of general laws - (Cons. 1875, Art. X, Sec. 2.) $-110$ 

2. Exemptions from Taxation .

The Constitution of 1820 had allowed the General Assembly to use its discretion in allowing exemptions from taxation; the Constitution of 1865 rigorously prohibited exemptions except in certain enumerated cases. In the provisions of the present Constitution on this subject a slight reaction is to be noticed; for while exemptions are prohibited except in the instances enumerated by the Consitution, the exceptions are broader than in the previous Constitution. Certain amounts of property used for religious, school, or charitable purposes are exempted; also such property as may be used exclusively for agricultural or horticultural societies. All exemptions must be made by general laws . (Cons. 1875, Art. X, Sec.6.)

(3). General Financial Regulations.

The Constitution abolished an Ordinance adopted by the State in 1865, which provided for the payment of the state debt, and substituted in liev therof an annual tax to be paid into the state Treasury, sufficient to pay the annual interest on the bonded debt of the state, and to decrease the principal amount by at least $\$ 250,000$ each year .

(Cons. 1875, Art. $X$, Sec. 14.)

The manner in which the funds of the state shall be kept by the Treasurer, and his accounts, were regulated by the constitution in general terms.

(Cons. 1875, Art. $X$, Secs. 10, 15, 16.) 

- The order in which appropriations of the public funds shall be made, and matters of detail to be followed in the disbursement of the state moneys were prescribed with much greater partioularity than had been the case in the Constitution of 1865 . (Cons. 1875, Art. X, Seca. 10, 19).

All money arising from any loan or debt contracted by the state or any of its local subdivisions must be applied to the purposes for which such money was obtained, or to the repayment of the debt or loan.

$$
\text { (Cons. 1875, Art. } \mathrm{X}, \text { Secs. 10, 20.) }
$$

The various provisions of this Article limit the financial powers of the General Assembly to a much greater extent than had been done by any previous constitution. (a). Corporations - (1). In General.

The present Constitution contains many regulations in regard to corporations not found in the Constitution of 1865 . Except to provide that corporations should not be created by special laws, and to impose a double liability on stockholders, the latter instrument had left the subject practically untouched.

The Constitution of 1875 provides how shareholders in corporations shall be entitled to vote their stock in elections of directors. Each shareholder may cast as many votes as he has shares of stock, multiplied by the number of directors to be elected; these votes may all be cast for one 

candidate, or distributed among two or more candidates. Directors cannot be elected in any other manner.

$$
\text { (Cons. 1875, Art. XII, Sec. 6.) }
$$

Every corporation is limited to the business authorized by its charter; no corporation can hold real estate for a longer period than 6 years, except such as is necessary and proper for carrying on its authorized business. (Cons. 1875, Art. XII, Sec. 7.)

The Constitution provides that no corporation can issue stock or bonds except for a bona fide consideration actually received by it, and all fictitious increase of stock or debt is declared void. Stock and bonded debt cannot be increased except in pursuance of the authority of general laws, with the consent of the majority of stock, after giving public notice of the intended increase .

$$
\text { (Cons. 1875, Art. XII, Sec. 8). }
$$

The liability of stockholders in corporations was fixed at the amount of their stook. The previous constitution had made them liable in double this amount. Preferred stock can only be issued with the consent of all the stockholders. (Cons. 1875, Art. XII, Secs. 10,11).

The General Assembly may always appropriate, under the power of eminent domain, the property and franchises of corporations. The right of trial by jury is guaranteed in all trials involving the power of eminent domain, when a corporation is a party on either side of any such case. (Cons. 1875, Art. XII, Sec. 4.) 

Within the meaning of this Article of the Constitution the word "corporation" includes joint stock companies and all associations possessing powers not enjoyed by individuals or partnerships . (Cons. 1875, Art, XII, Sec. 11).

The Constitution fixed a schedule of fees to be paid by all corporations oreated by the state. These fees are graduated according to the amount of capital stock, and a fee is demanded for every increase of capital stock. The payment of these fees is a prerequisite to corporate existence. (Cons. 1875, Art. XII, Sec. 2I).

(2). Railroad Corporations .

Intensive regulation of railroads was introduced by the present Constitution. The Constitution of 1865 had left the subject entirely to the control of the General Assembly.

Railroads are declared to be public highways; and as a means of controlling them for the benefit of the public, the legislature is enjoined to pass laws to prevent extortion and discrimination; also to pass laws fixing reasonable maximum rates for the transportation of passengers and freight . (Cons. 1875, Art.XII, Sec. 149.

Bvery railroad organized or doing business within the State must have an office within the state, where it shall transact business, make transfers of stook, and keep its books for public inspection. The directors of every railroad doing business within the state must hold one meeting in the state annually, upon notice given .

(Cons. 1875, Art. XII, Sec. 15). 

The Constitution expressly declares that discrimination by railroads is unlawful. They cannot charge a greater amount for the transportation of freight and passengers a less distance than is charged for a greater distance. This rule is not to prevent the issuance of excursion or commutation tickets at a discount. Discrimination between individuals and transportation companies, and the giving of rebates, is forbidden. The giving of free transportation, or reduced rates, to certain state officials, is also prohibited (Cons. 1875, Art. XII, Secs. 12, 23, 24.)

All railroad companies are given the right to construct their lines between any points in the state, and to connect with other lines at the boundaries of the state. Every railroad may intersect the line of any other railroad, and they must receive and carry each other's freight, passengers, and cars without discrimination.

(Cons. 1875, Art. XII, Sec. 13).

The consolidation of parallel lines of railroad in the state, in any manner whatsoever, is prohibited by the Constitution. Such lines of railroad cannot have officers in common. This is a most important provision, and insures the people of the state against the abolition of competition by parallel lines of railroad, which might be industrially ruinous to the districts affected.

$$
\text { (Cons. 1875, Art. XII, Sec. 17.) }
$$

When any railroad company organized under the laws of the state consolidates with any foreign railroad company, 

such former company does not thereby become a foreign corporation; but the courts of the state retain jurisdiction as if no consolidation had taken place.

(Cons. 1875, Art. XII, Sec. 18).

The Constitution declares that the rolling stock and all other movable property of railroads shall be subject to execution and sale as if the property of individuals. The General Assembly is forbidden to pass any law exempting such property from sale under execution.

$$
\text { (Cons.1875, Art. XII, Sec. 16). }
$$

(3). Banking Corporations .

Several prohibtions upon the legislative power in regard to banks were noticed in a previous section of this discussion. The Constitution makes it a orime for any managing officer of any bank to receive deposits or create debts upon behalf of any bank, after the officer has knowledge that such bank is insolvent, or in failing circumstances . In addition, such officer is made individually liable for all deposits received or debts incurred.

$$
\text { (Cons . 1875, Art. XII, Sec. 27.) }
$$

$(e)$.

\section{Militia .}

The provisions of the Constitution of 1865 which declared what classes of persons should be liable to military service were reenacted, with the proviso that no person who is religiously scrupulous of bearing arms can be compelled to do so. Such persons may, however, be compelled to pay 

an equivalent therefor. (Cons. 1875, Art. XIII, Sec. 1.)

A new provision enacted by the present Constitution requires the General Assembly to provide for the organization and equipment of the militia as nearly as possible in conformity with the regulations follwed by the armies of the United States. (Cons. 1875, Art. XIII, Sec.2).

Company and regimental officers are elected as under theterms of the previous Constitution; but it is provided that the Governor shall appoint the Adjutant General, Quartermaster General, and his other staff officers. He also appoints, with the advice and consent of the senate, all Major and Brigadier Generals.

(Cons. 1875, Art. XIII, Secs. 3,6.)

The Constitution authorizes the formation of volunteer companies of infantry, cavalry, and artillery, and gives the militia and volunteer forces the privelege of exemption from arrest, except in cases of treason, felony, and breach of the peace, during their attendance on military meetings.

(Cons. 1875, Art. XIII, Secs.4,5.)

Finally, it is provided that the General Assembly shall provide for the safekeeping of the public records, arms, relies, ete.

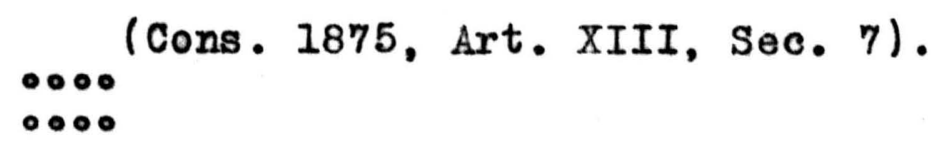

The numerous provisions of the Constitution of 1875 which were introduced by its framers to positively regulate matters which it was deemed wise to place beyond the reach of the legislative power, imposed greater limitations upon the powers of the General Assembly than had been done by any previous constitution of the state. 





\section{APPENDIX "A".}

\section{TABIE}

Showing the apportionment of membership in the lower house of the General Assembly of Missouri, as fixed by the General Assembly at its apportioning sessions from 1822 to 1841, inclusive. The apportionment for the lst. General Assembly was fixed by the Constitution of 1820 .

General Assemblies. ...2-3..4-5..6-7..8-9..10-11..12-13.

Counties.

Cape Girardeau.......6.6.....3...3....3....2. . St. Iouis $\quad \ldots \ldots \ldots \ldots 6 \ldots \ldots 4 \ldots \ldots 5 \ldots \ldots 6 \ldots \ldots 7 \ldots \ldots 7$. Howard Cooper Boone St. Charles Washington Montgomery

Franklin Pike $\ldots \ldots \ldots \ldots 5, \ldots . \ldots 3 \ldots \ldots 4 \ldots \ldots 4 \ldots \ldots 3$. $\ldots \ldots \ldots \ldots 3 \ldots \ldots 2 \ldots \ldots 2 \ldots \ldots 2 \ldots \ldots 3 \ldots \ldots .2$. $\ldots \ldots \ldots 3 \ldots \ldots 2 \ldots \ldots 3 \ldots . \ldots 4 \ldots \ldots 5 \ldots \ldots 3$. $\ldots \ldots \ldots .3 \ldots \ldots 2 \ldots \ldots 2 \ldots \ldots 2 \ldots \ldots 2 \ldots \ldots 2$. $\ldots \ldots \ldots .3 \ldots \ldots 2 \ldots \ldots 3 \ldots 3 \ldots \ldots 3 \ldots \ldots \ldots 2$. $\ldots \ldots \ldots \ldots 2 \ldots \ldots 1 \ldots \ldots 1 \ldots \ldots 1 \ldots \ldots 1 \ldots \ldots \ldots 1$. $\ldots \ldots \ldots 2 \ldots \ldots 1 \ldots \ldots 1 \ldots \ldots 1 \ldots \ldots 2 \ldots \ldots .2$.

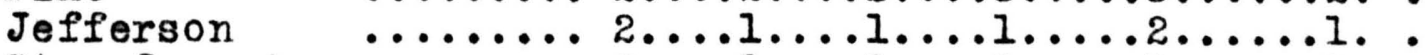
Ste. Generiere................................ Cole $\quad \ldots \ldots \ldots \ldots \ldots \ldots \ldots \ldots \ldots \ldots \ldots 2 \ldots \ldots 2 \ldots \ldots \ldots 2 . \ldots$ Clay Jackson Lafayette Iincoln Marion

Perry Rando Iph Callaway Monroe Ralls

Ray Platte

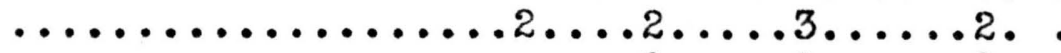

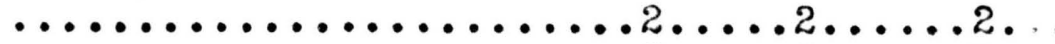

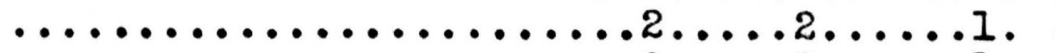
$\ldots \ldots \ldots \ldots \ldots \ldots \ldots \ldots \ldots \ldots \ldots \ldots \ldots$ $\ldots \ldots \ldots \ldots \ldots \ldots \ldots \ldots \ldots \ldots \ldots \ldots$

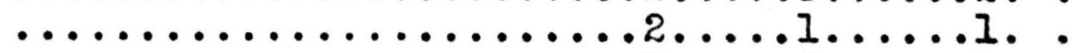

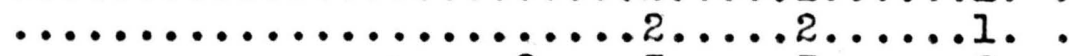

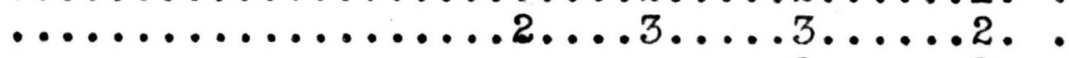

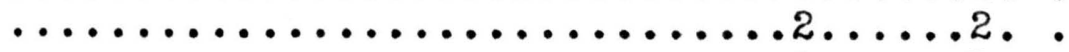
$\ldots \ldots \ldots \ldots \ldots \ldots \ldots \ldots \ldots \ldots \ldots \ldots$ $\ldots \ldots \ldots \ldots \ldots \ldots \ldots \ldots \ldots \ldots \ldots \ldots \ldots$ $\ldots \ldots \ldots \ldots \ldots \ldots \ldots \ldots \ldots \ldots \ldots \ldots$

For the sessions of the General Assembly enumerated above, the representation of all other counties in the state was fixed at one (I) member each. 



\section{APPENDIX "B".}

Tables showing the arrangement of counties in Senatorial

Districts, the increase in Districts, and the apportionment of Senators among Districts during the period that the several Constitutions of the state have been in force, to the year 1901 .

(The figures in parentheses() indicate the number of senators the district was entitled to elect).

2nd. and 3rd. General Assembly . (I Territorial Laws, 906).

1st. District. (I)

Clay.

Ray,

Liliard

Chariton

2nd. District.

Howard

3rd. District.

Boone.

4th. District.

Saline

Cooper

Cole

5th. District.

Callaway

Gasconade

Franklin

6th. District.

Montgomery

Iincoln

7th. District.

Pike

Ralls 8th. District. (I)

St. Charles

9th. District. (1)

st. Louis.

10th. District. (1)

Jefferson

Washington

Ilth. District. (I)

Ste. Genevieve

St. Franco is

Perry

12th. District. (I)

Madison

Wayne

13th. District. (I)

Cape Girardeau

14th. District. (I)

Scott

New Madrid

(Total number districts, 14).

(Total number senators, 14 ). 

4th. and 5th. General Assemblies . (II Laws 1825, page 508).

1st. District. (I)

Scott

New Madrid

2nd. District. (1)

Madison

Ripley

Wayne

3rd. District. (1)

Ste. Genevieve

Perry

St. Francois

4th. District. (1)

Cape Girardeau

5th. District. (2)

St. Iouis

Jefferson

6th. District. (I)

Washington

7th. District. (I)

Cole

Gasconade

Franklin

8th. District. (1)

St. Charles

Jincoln

9th. District. (I)

Callaway

Montgomery 10th. District. (I)

Pike

Ralls

1lth. District. (I)

Boone

12th. District. (I)

Howard

Chariton

13th. District. (I)

Ray

Clay

Lafayette (Iillard)

14th. District. (I)

Cooper

Saline

(Total number districts, 14).

(Total number senators, 15). 

6th. and 7th. General Assemblies. (II Territorial Laws, 14l.)

1st. District. (I)

Scott

Now Madrid

2nd. District. (I)

Madis on

Wayne

3rd. District. (1)

Ste. Genevieve

Perry

St. Franco is

4th. District. (I)

Cape Girardeau

5th. District. (2)

St. Iouis

Jefferson

6th. District. (1)

Washington

7th. District. (1)

Cole, Gasconade,

Franklin

8th. District. (I)

St. Charles

Iincoln 9th. District. (I)

Callaway

Kontgomery

10th. District. (2)

Pike

Ralls

Marion

IIth. District. (I)

Boone

12th. District. (2)

Howard

Chariton

13th. District. (1)

Ray

Clay

14th. District. (I)

Lafayette

Jacks on

15th. District. (I)

Cooper

Saline

(Total number districts,15.)

(Total number senators, 19.) 

8th. and 9th. General Assemblies. (II Territorial Laws, 371.)

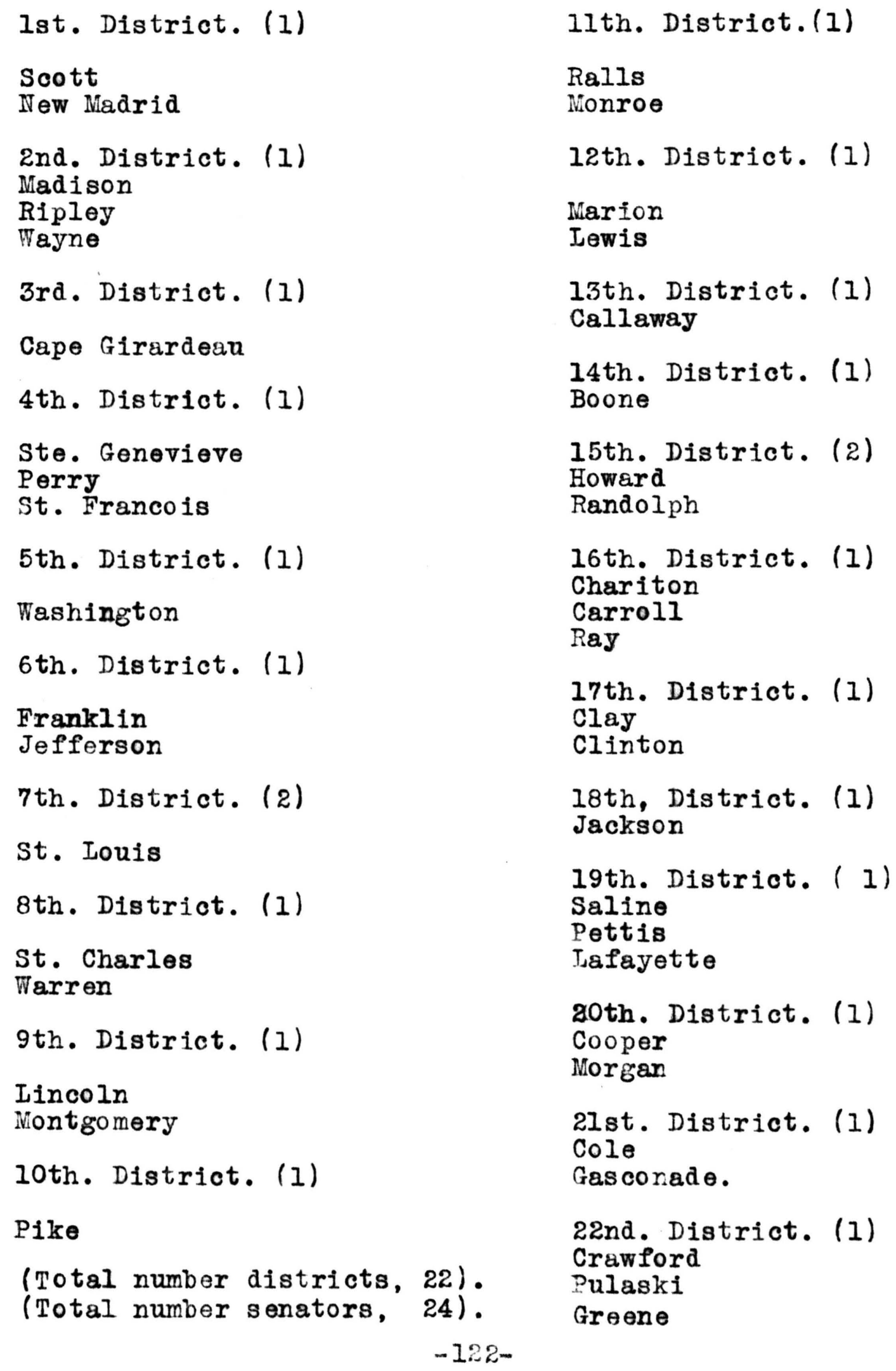



10th. and 11th. General Assemblies. (Laws 1836, page 5.)

lst. District. (I)

st. Charles

Warren

2nd. District. (I)

Lincoln

Montgomery

3rd. District. (1)

Pike

4th, District. (2)

Marion, Ralls,

Lewis , Clark.

5th. District. (1)

Monroe

Shelby

6th. District. (I)

Callaway

7th. District. (2)

Boone

Audrain

8th. District. (2)

Howard

9th. District. (1)

Randolph

Macon

10th. District. (I)

Chariton

Carroll

Livingstone

Iinn

11th. District. (I)

Ray

Daviess

Caldwell

12th. District. (2)

Clay

Clinton

13th. District. (1)

Scott, Stoddard, New Madria. 14th, District. (1)

Madison

Wayne

Ripley

15th. District. (I)

Cape Girardeau

16th. District. (I)

Perry, St. Francois,

Ste. Genevieve

17th. District. (1)

Washington

18th. District. (2)

Franklin, Jefferson, Crawford.

19th. District. (3)

St. Louis

20th. District. (1)

Cole, Gasconade,

Miller.

21st. District. (I)

Norgan

ulaski

22nd. District.

Cooper

23rd. District.

Pettis, Saline,

Benton

24th. District.

Johnson, Rives,

Lafayette

25th. District. (I)

Greene, Barry,

Polk, Taney

26th. District. (1)

Jacks on

Van Buren.

(Total number districts, 26)

(Total number senators, 33) 

12th. and 13th. General Assemblies. (Laws 1840-1, page 9).

1st. District. (1)

St. Charles

Farren

2nd. Diatriot. (1)

Iincoln, Audrain, Montgomery

3rd. District. (1)

Pike

4th. District. (2)

Ralls, Narion, Monroe

5th. District. (1) Shelby, Lewis, Clark, Adair, Sootland.

6th. District. (1) Linn

Grundy

Iivingston

7th. District. (1) Randolph

Chariton

8th. Distriot. (I) Carroll, Caldwell, Daviess, Clinton

9th. District. (2) Ray, Clay, Platte.

10th. District. (1) Holt, Andrew,

Buchanan

11th. District. (I) Howard

12th. District. (1)

Boone

13th. District. (1) Callaway

14th. District. (1) Jackson, Van Burm, Bates 15th. District. (I)

Lafayette, Johnson

16th. District. (I)

Saline. Pettis, Bemton

17th. District. (1)

Jasper, Newton,

Barry, Dade

18th. District. (1)

Rives, St. Clair,

Polk, Niangua

20th. District. (1)

Korgan, Miller,

Kinderhook, Pulaski

2lst. District. (1)

Cooper

22nd. District. (I)

Crawford, Gasconade, Washington.

23rd. District. (I)

Franklin, Jefferson

24th. District. (3)

St. Louis

25th. District. (I)

Ste. Geneviere,

St. Francols,

26th. District. (1)

Shannon Madison,

Wayne, Ripley

27th. District. (1)

Cape Girardeau

28th. District. (1)

Scott, New Nadrid,

Stoddard

29th. District. (1)

Cole , Osage

(Total number distriots, 29).

(Total number senators, 33). 

14th. and 15th. General Assemblies. (R.S.1845, page 113.)

1st. District. (1)

St. Charles

Iincoln

2nd. District. (1)

Pike, Ralls

3rd. District. (1)

Marion, Monroe

4th. District. (I)

Lewis, Clark,

Scotland, Knox,

Schuyler

5th. District. (I)

Sullivan, Putnam,

Grundy, Mercer,

Harrison, Gentry

6th District. (1)

Holt, Andrew,

Atchison, Nodaway

7 th District. (1)

Buchanan, DeKalb,

clinton

8th District. (2)

Clay, Ray, Platte

9th District. ( 1)

Iivingston, Linn,

Carroll, Daviess,

Caldweli

10th. District. (f)

Howard, Chariton

Ilth District.

Macon, Adair,

Shelby, Randolph

12th. District. (1)

Boone, Audrain

13th District. (I)

Callaway

Montgomery

27th. District. (1)

Cooper, Moniteau 14th. District. (1)

Cole, Miller, Morgan

15th. District. (I)

Franklin, Warr en

16th. District. (2)

Crawford, Washington,

Gasconade, Ozark, Puiaski

17th. District. (1)

Ste. Genevieve, Perry,

St. Franco is.

18th. District. (I)

Cape Girardeau, Wayne.

19th. District. (I)

Scott, New Madrid, Dunklin,

Mississippi, Stoddard

20th. District. (1)

Reynolds, Shannon, Texas,

Madison, Ripley, Oregon,

Wright

21st. District.

Greene, Taney

22nd. District. (I)

Lawrence, Barry, Newton, Jasper

23rd. District. (I)

Polk, Hickory, Camden, Dallas

24th. District. (I)

St. Clair, Bates, Henry,

Cedar, Dade

25th. District. (2)

Johnson, Jackson,

Van Buren, Lafayette

26 th. District. (1)

Pettis, Saline, Benton.

(Total number districts, 28)

(Total number senators, 33)

28th. District. (3)

St. Iouis. 

16th, and 17th. Ceneral Assemblies. (Laws 1848-9, page 14.)

1st. District. (I)

st. Charles, Iincoln

2nd. District. (1)

Pike. Ralls

3rd. District. (1)

Marion, Monroe

4th. District. (1)

Lewis, Clark,

Knox,' Schuyler,

Scotiand

5th. District. (1)

Iivingston, Iinn,

Carroll, Daviess

6th. District. (I)

Holt, Andrew,

Atchison, Nodaway

7th. District. (I)

DeKalb, Gentry,

Buchanan

8th. District. (I)

Platte,clinton

9th. District. (1)

Clay, Ray, Caldwell.

10th. District. (1)

Grundsy, Sullivan,

Putnam, Harrison,

Mercer.

11th. District. (I)

Howard, Chariton

12th. District.

Macon, Adair,

Randolph, Shelby

13th. District. (I)

Boone, Audrain

14th. District. (I)

Callaway, Montgomery

15th. District. (1)

Warren, Gasconade 16th. District. (I)

Perry, Jefferson, St. Francois

17th. District. (I)

Cape Girardeau, Wayne.

18th. District. (1)

Scott, New Madrid, Dunklin,

Mississippi, stoddard

19th. District. (I)

Shannon. Texas, Ripley,

Reynolds, Madison, Oregon,

Wright

20th. District. (I)

Greene, Taney, Ozark

2lst. District. (I)

Lawrence, Barry,

Newton, Jasper

22nd. District. (I)

Dade, Cedar, Bates

23rd. District. (I)

Jackson, Van Buren

24th. District. (I)

Lafayette, Johnson

25th. District. (I)

Benton, Henry, Pettis, Saline

26th. District.

Cooper, Moniteau

27th. District. (I)

Cole, Osage, Morgan, Miller

28th. District. (I)

Polk, Hickory, Camden, Dallas

29th. District. (I)

Crawford, Washington,

Pulaski

30th. District. (4)

St. Louis

(Total number districts, 30$)$
(Total number senators, 33). 

lst. District. (I)

St. Charles,

Warren, Montgomery

2nd. District. (I)

Pike, Iincoln Audrain

3rd.District. (I)

Boone, Callaway

4th. District. (I)

Ralls, Marion, Monroe

5th. District. (I)

Lewis, Clark,

scotland

6th. District. (1)

Howard, Chariton,

Randolph

7th. District. (1)

Knox. Macon,

Shelby, Adair,

Schuyler

8th. District. (I)

Iinn, Sullivan, ,

Putnam, Iivingston

9th. District. (1)

Daviess, Mercer,

Grundy, Harrison

10th. District. (1)

Ray, Carroll, Clinton, Caldwell

IIth. District. (I)

Holt, Andrew,

Atchison, Nodaway

12th. District. (I)

DeKalb, Gentry,

Buchanan

13th. District. (I)

Platte, Clay

14th. District. (I) Jackson, Cass, Bates 15th. District.

Johnson, Henry,

Benton, StClair

16th. District. (I)

Saline, Pettis

Lafayette

17th. District. (1)

Verhon, Barton, Dade,

Jasper, Cedar

18th. District. (I)

Newton, Barry,

Lawrence, McDonald

19th. District. (I)

Greene, Stone,

Taney, Webster

20th. District. (I)

Polk, Dallas,

Leclede, Hickory

2lst. District. (I)

Franklin, Osage,

Gasconade

22nd. District. (I)

Dent, Texas, Wright,

Pulaski, Douglass,

Phelps, Crawford

23rd. District. (I)

Washington, Jefferson,

St. Francois, Ste. Genevieve

24th. District. (I)

Ripley, Madison, Iron, Wayne, Butler, Shannon, Reynolds, Oregon, Howeil

25th. District. (I)

Stoddard, Dunklin, Pemiscot, New Nadria, Mississippi

scott.

26th. District. (I)

, Perry,

Cape Girardeau, Bollinger

27th. District. (1)

Cole, Miller, Camden, Maries 

28th. District. (I)

Cooper,

Morgan,

Moniteau

(Total number districts, 29. Total number senators, 33.) 



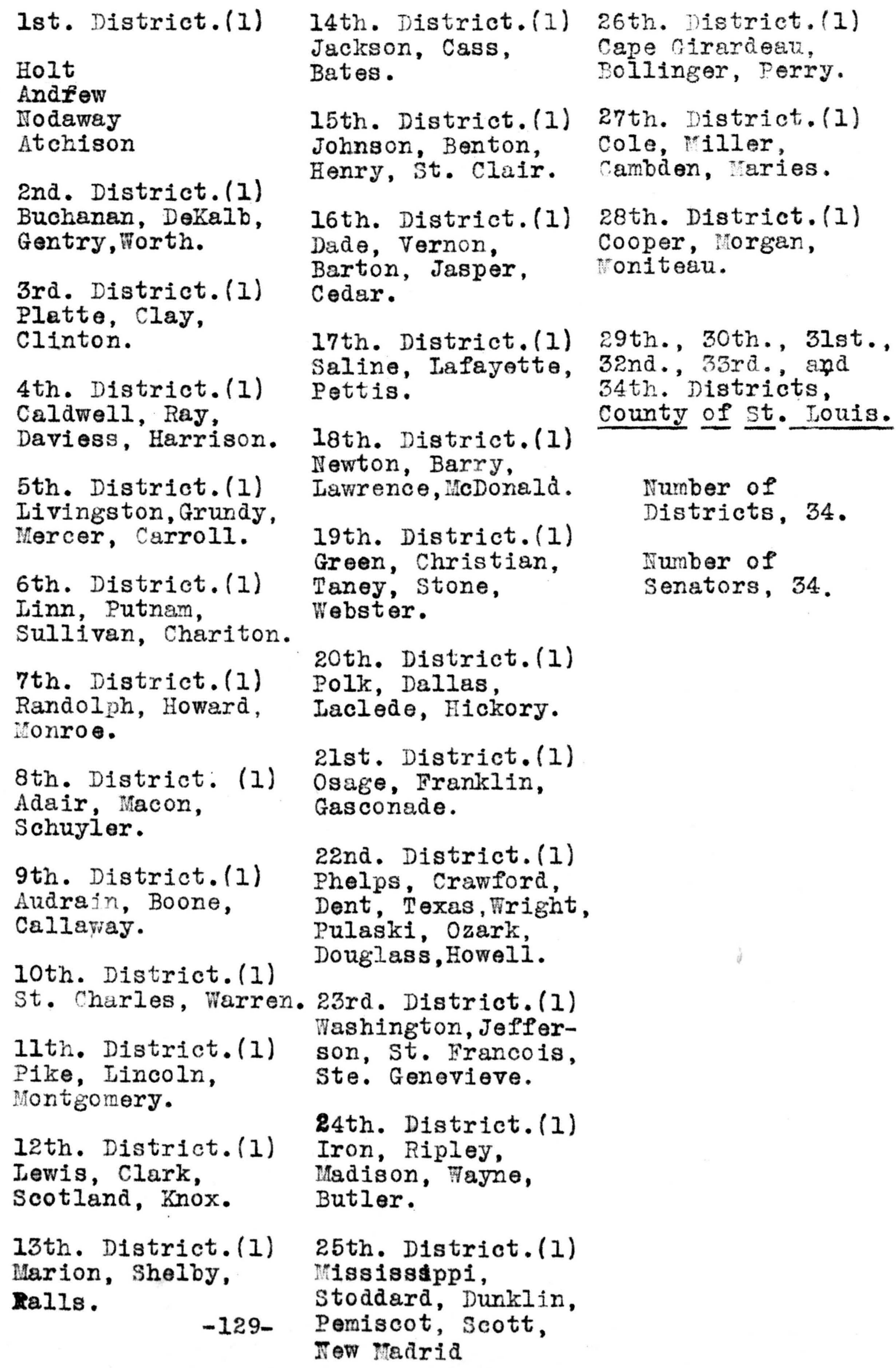
llth. District.(1) washington, Jeffer-

Henry, St. Clair. Cambden, Naries.

22nd. District. (I)

Phelps, Crawford, Dent, Texas, Wright, Pulaski, Ozark, Douglass, Howell. ste. Generieve.

24th. District. (I)

Iron, Ripley,

Madison, Tayne,

Butler.

25th. District. (I)

Mississspi, Stoddard, Dunklin, -129- Pemiscot, scott,

New Madrid

26th. District.(I)

Cape cirardeau,

Bollinger, Perry.

27th. District. (I)

cole, riller,

8th. District. (I)

Cooper, Morgan,

Noniteau.

29th., 30th., 3lst.,

32nd., 33ra., and

34th. Districts,

county of st. Jouis.

Number of

Districts, 34.

Number of

Senators, 34. 

(Laws 1882, Preface.)

Apportionment made by state officers under the authority conferred by sec. 7 of Art. IV, Cons. 1875.

lot District.
Atchison
Holt
Nodaway

2nd. District. Buchanan Andrew

3rd. District. clay, clinton, Platte

4th. District. Daviess, DeKalb, Gentry, Worth, Harrison

5th. District. Iivingst one Grundy, Putnam, Mercer

6th.District. Chariton, Iinn, sullivan

7 th. District. Macon, Randolph Adair, Schuyler

8th. District. Carroll, Ray, Caldwell

9th. District. Howard, Boone.

10th. District. Warren, st. Chas. Wontgomery

Ilth. District. Audrain, Pike, Iincoln

12th. District. Clark, Lewis, Scotland, Knox 13th. District. Marion, Monroe Ralls, Shelby

14th. District. Cole, Cooper, Maries, Niller, Morgan, Moniteau

15th. District. Saline, Pettis, Benton, Cambden.

16th. District. Bates, Cass, Hickory

17th. District. Lafayette Johnson

18th. District. Newton, McDonald, Barry, stone Lawrence

19th. District. Greone, Ozark, Webster, Taney, Christian, Douglass

20th. District. Dade, Cedar, Polk, Dallas, Hickory, st. Clair

2lst. District. Franklin, Osage, Crawford, Gasconade

22nd. District. Phelps, Pulaski, Laclede, Dent Howell, Shannon, Texas, Wright

23rd. District. scott, stoddard, Mississippi, New Madrid Dunklin, Pemiscot 24th. District. Iron, Madison Butler, carter Oregon, Ripley, Reynolads, Wayne

25th. District. Jefferson, St.Louis, Washington

26th. District. Cape Girardeau Bollinger St. Francois, Perry ste. Genevieve 27th. District. Jackson

28th, District. Vernon, Barton, Jasper

29th., 3oth., 31st., 32nd., 33rd., and

34th. Districts, City of St. Iouis.

Each district elected one senator)

Number of districts, 34.

Number of senators, 34. 

(Laws 1885, page 251).

The apportionment of counties into senatorial districts made by the General Assembly in 1882 was slightly changed. The county of Crawford was transforred from the 2lst. Senatorial District to the 22nd. Senatorial District. The apportionment of the remaining counties of the state as made by the Law of 1882 , (supra) remained unchanged. By the Iaw of 1885, the 21st. and 22nd. Senctorial Districts consisted of the following counties respectively:

2lst. District.

22na. District.

Franklin

Gasconade

Osage

Phelps, Pulaski

Laclede, Crawford, Dent, Howell, Texas Shannon, Wright.

Each district continued to elect one senator, as before. 



\section{(Laws 1901. Appendix.)}

Apportionment made by state officers under the authority conferred by sec. 7 of Article IV of Cons. of 1875.

Ist. District. Atchison, Gentry, Nodaway, Worth

2nd, District. Buchanan

3ra. District. clay, clinton

DeKalb, Holt, Andrew, Platte

4th. District. Grundy, Hercer, Livingstone, putnam Harrison

5th. District. 7th. District. Jackson

6th. District. Chariton, Iinn Sulliven

8th. District. Carroll, Ray Caldwell, Daviess

9th. District. Adair, Inacon, Shelby, Boone

loth. District. Callaway, Warren Montgomery, st. Chas.

1Ith. District. Audrain, Pike Iincoln

12th. District. Clark, Lewis Knox, Schuyler Scotiand.

13th.. District. Narion, konroo Ralls, Randolph 14th: District:

Cambden, cooper, Howard, Morgan

Moniteau

15th. District. Benton, Pettis Hickory, Saline

16th. District. Bates, Cedar, Henry, st. clair

17th. District. Cass, Johnston, Lafayette

18th. District. Barry, Lawrence Newton, McDonald

19th. District. Christian, Dallas Ozark, Dauglass Polk, stone,. Taney, Vebster

20th. District. Barton, Dade Greene, Vernon

2lst. District. Butler, Bollinger Carter, Ripley, Dunklin, Wayne

Cape Girardeau

22nd. District. Howell, Oregon Shannon, Texas, Wright

23ra. District. Mississippi New Madrid, scott Pemiscot, stoddard

24th. District. Dent, Iron, Phelps Crawford, Reynolds, Washington 25th. District. Franklin, St.Iouis Gasconade

26th. District. Jefferson, Perry Madison, st. Francois - Ste. Genevieve

27 th. District. Cole, Iaclede Miller, Maries Osage, Pulaski

28th. District. Jasper

29th., 30th., 3ist., 32nd., 33 ra., and 34 th. Districts, City of st.Iouis.

(Each district elected ono senator.)

Number of districts. 34 . Number of senators, 34. 






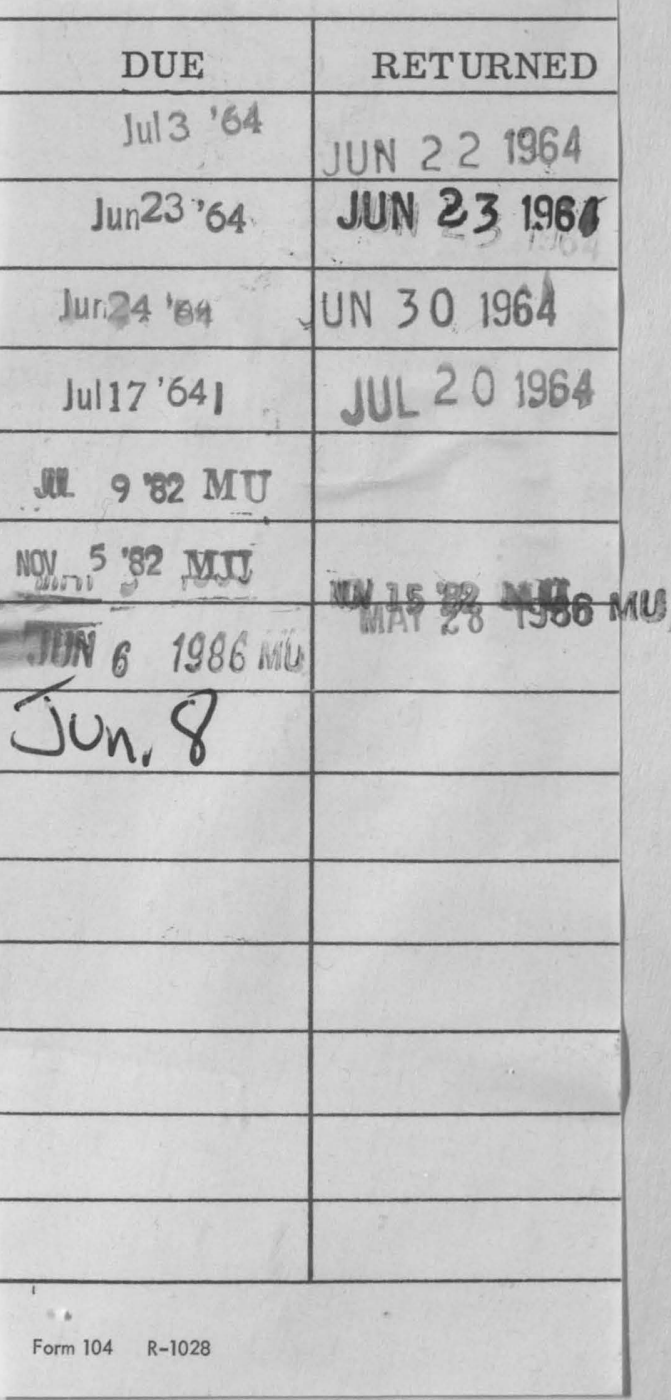


